Félix Valdés García

(coordinador)

\title{
El ángel de la
}

revolución caribeña

y latinoamericana

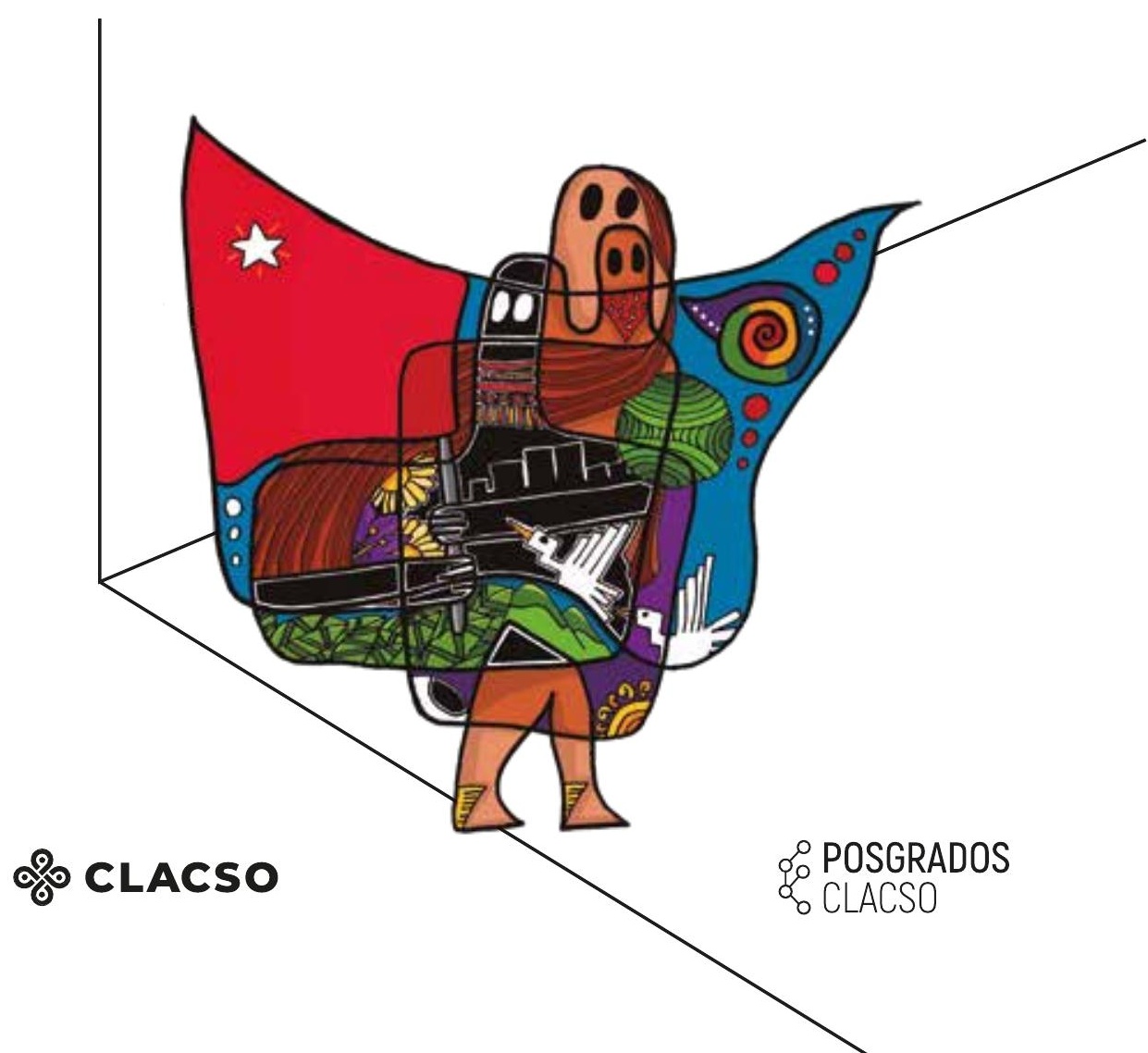


El ángel de la revolución caribeña y latinoamericana / Félix Valdés

García ... [et al.] ; editado por Félix Valdés García. - 1a ed.-

Ciudad Autónoma de Buenos Aires : CLACSO, 2019.

Libro digital, PDF - (Red de Posgrados/Arata, Nicolás)

Archivo Digital: descarga y online

ISBN 978-987-722-443-6

1. Revolución. 2. América y el Caribe. I. Valdés García, Félix, ed. CDD 301.098 


\section{El Ángel de la Revolución caribeña y latinoamericana}

Félix Valdés García

(coordinador)

Miguel Enríquez

Félix Valdés García

Carmen Castillo

Adrián Zapata 


\section{CLACSO}

Consejo Latinoamericano

de Ciencias Sociales

Conselho Latino-americano

de Ciências Sociais

Colección Red de Posgrados

Director de la colección - Nicolás Arata

\section{CLACSO - Secretaría Ejecutiva}

Karina Batthyány - Secretaria Ejecutiva

Nicolás Arata - Director de Formación y Producción Editorial

Pablo Vommaro - Director de Investigación

María Leguizamón, Lucas Sablich, Nicolás Sticotti - Equipo Editorial

\section{Equipo de la Red de Posgrados}

Coordinador del Espacio de Formación Virtual: Alejandro Gambina

Asistentes: Inés Gómez, Magdalena Rauch, Alejandro Cipolloni, Camila Downar y Sofía Barbuto

Diseño de tapa y colección: Ana Uranga

Corrección: Rosario Sofía y Celia Ríos

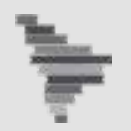

\section{LIBRERIÁ LATINOAMERICANA Y CARIBEÑA DE CIENCIAS SOCIALES CONOCIMIENTO ABIERTO, CONOCIMIENTO LIBRE}

Los libros de CLACSO pueden descargarse libremente en formato digital o adquirirse en versión impresa desde cualquier lugar del mundo ingresando a www.clacso.org.ar/libreria-latinoamericana

ISBN 978-987-722-443-6

(C) Consejo Latinoamericano de Ciencias Sociales I Queda hecho el depósito que establece la Ley 11723.

No se permite la reproducción total o parcial de este libro, ni su almacenamiento en un sistema informático, ni su transmisión en cualquier forma o por cualquier medio electrónico, mecánico, fotocopia u otros métodos, sin el permiso previo del editor.

La responsabilidad por las opiniones expresadas en los libros, artículos, estudios y otras colaboraciones incumbe exclusivamente a los autores firmantes, y su publicación no necesariamente refleja los puntos de vista de la Secretaría Ejecutiva de CLACSO.

Los trabajos que integran este libro fueron sometidos a un proceso de evaluación por pares.

\section{CLACSO}

Consejo Latinoamericano de Ciencias Sociales - Conselho Latino-americano de Ciências Sociais

Estados Unidos 1168 I C1023AAB Ciudad de Buenos Aires I Argentina

Tel [54 11] 43049145 I Fax [54 11] 43050875 I <clacso@clacsoinst.edu.ar> I <www.clacso.org> 
"La memoria es la vida, siempre acarreada por los grupos vivos. Y, a este respecto, está en evolución permanente, abierta a la dialéctica del recuerdo y la amnesia, inconsciente de sus sucesivas deformaciones, vulnerable a todos los usos y manipulaciones, susceptible de estar latente durante mucho tiempo y de manifestar súbitas revitalizaciones. La historia es la reconstrucción siempre problemática e incompleta de lo que ya no es. La memoria es siempre un fenómeno actual, un vínculo vivido en el eterno presente: la historia, una representación del pasado. Dado que es emocional y mágica, la memoria solo se acomoda a aquellos detalles que la confortan: se nutre de recuerdos borrosos, chocantes, globales o flotantes, particulares o simbólicos, sensibles a todas las transferencias, velos, censura o proyecciones".

Pierre Nora, Los libros de la memoria

“Érase una vez, ¿en otro tiempo, en otro mundo?, un golpe de Estado. Chile, 11 de septiembre de 1973. Las fuerzas armadas detienen, torturan, matan a todos aquellos que aspiran a y luchan por una sociedad de justicia social $y$ de libertad. Necesitan aplastar, quebrar en mil pedazos ese Nosotros en comunión. Para extirpar el alma que amenazaba, más allá de los cuerpos abatidos, pretendieron arrasar, destruir todo aquello que nutría aquel espíritu revolucionario. En las esquinas, en las veredas de las ciudades, en los poblados del campo, el fuego consumía libros, revistas, documentos, afiches, discos... Esas fogatas, custodiadas por oficiales y soldados hilarantes, convencidos de que de las cenizas nada podría resurgir, atemorizaron, y era normal, a las personas que se sabían en peligro por poseer las canciones de Víctor Jara o Violeta Parra, los poemas de Neruda o de Gonzalo Rojas, los himnos de la Unidad Popular interpretados por Quilapayún, Inti Illimani, los Illapu... Las ediciones de la editorial Quimantú, cualquier folleto sobre la Revolución cubana... La ignorancia de los represores condujo a excesos insospechados y poco a poco todo libro, todo papel, toda palabra, se convertía en peligrosa... Para preservar la vida teníamos que proceder a destruir nuestras pertenencias, con extrema discreción, también nosotros, los perseguidos".

Carmen Castillo. Prólogo a Miguel Enríquez. Mi felicidad es la lucha. 



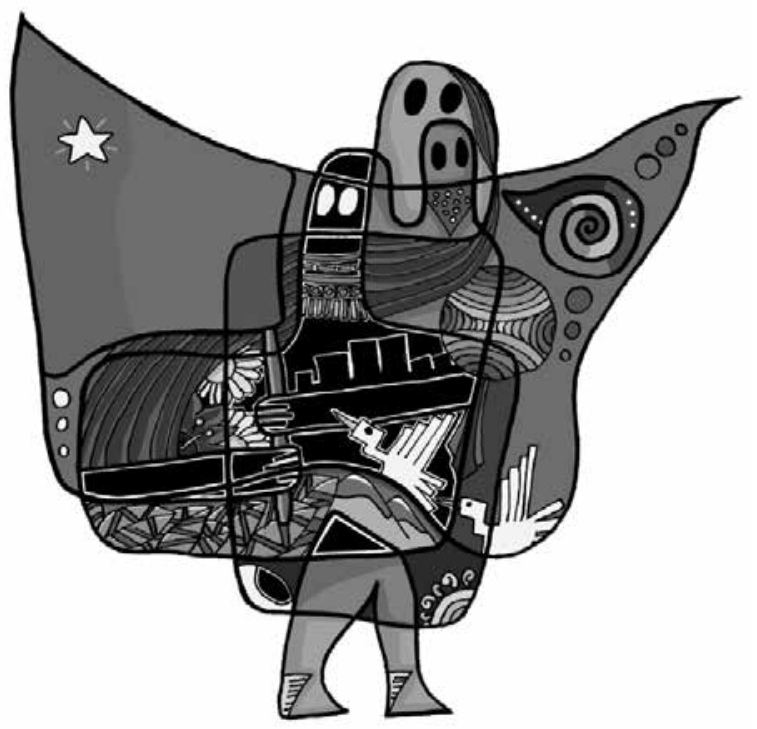

El Ángel de la Revolución, una recreación de la obra de Paul Klee, Engelshut (1931), de Carla Valdés León. Diseño de Roberto Chávez Miranda. 



\section{Pensar en clave de transmisión}

La colección Posgrados reúne trabajos que profesores y profesoras construyen cotidianamente en el entramado de la Red de Posgrados de CLACSO, un espacio cuyo propósito es desarrollar propuestas de formación en el campo de las ciencias sociales y las humanidades.

A través de la Red de Posgrados, CLACSO impulsa el diálogo de saberes entre estudiantes que provienen de la academia, de la función pública, que se desempeñan como líderes y lideresas sociales, entre otros.

Tanto en la plataforma virtual como en las escuelas de posgrado, las propuestas formativas recuperan y actualizan tradiciones del pensamiento social latinoamericano y caribeño, promueven la reflexión crítica y creativa, y estimulan el desarrollo de nuevos enfoques teóricos y metodológicos para el estudio de las experiencias nacionales y regionales, desde una visión comparada. 
Esta colección aspira a reunir algunas de esas producciones para colocarlas en circuitos de lecturas más amplios.

Convencidos y convencidas de que no hay mayor acto de investigación que preparar una clase, las producciones que alojan estas páginas fueron escritas desde diferentes posiciones docentes, comprometidos con la transmisión del conocimiento, la construcción de lazos intergeneracionales y la puesta en común de experiencias que contribuyan con uno de los objetivos del Consejo: formar nuevas camadas de investigadores e investigadoras para el desarrollo de las ciencias sociales y las humanidades en perspectiva latinoamericana y caribeña.

Nicolás Arata 
¿Por qué el Ángel de la Revolución caribeña

y latinoamericana?

FÉLIX VALDÉs GARcíA

Hay que crear una nueva legalidad

Miguel EnRíquez

Historias desencadenadas

Carmen Castillo

Vestimenta étnica para un "genocidio" político

AdRIÁN ZAPATA

Revoluciones en el Caribe: La memoria

y los peligros del silencio

FÉLIX VALDÉS GARCÍA

Sobre los autores y autoras 



\section{¿Por qué el Ángel de la Revolución caribeña y latinoamericana?}

\section{Felix Valdés García}

En un texto que reproduciremos más adelante, Carmen Castillo cuenta que una cita de John Berger, regalo de Diego Tatián, y sus diálogos con Macarena Aguiló, fueron para ella un encuentro decisivo. “Cada vez que se despierta el deseo de aportar algo en algún taller, exposición o texto - dice Carmen-, surge un escritor para guiarme".

Esta vez ha sido la lectura de El ángel de la barricada, de Diego Tatián (2009) ${ }^{1}$, filósofo argentino, lo que le ha iluminado de manera contundente. Este autor expresa su "sentir" y, con la belleza de su escritura, da claridad a una manera de pensar y actualizar nuestras memorias que a Carmen le parece importante compartir.

1 Tatián, D (2019). El ángel de la barricada. Haroldo, Revista del Centro Cultural de la Memoria Haroldo Conti, 12 de junio. 
La memoria de las rebeliones reviste un inmediato significado político, afirma, pues cuando las reinscribimos en una narración traducible, hacemos con ellas "una ofrenda de sentido, no para la repetición sino para la disrupción y para la invención". Sin esa acción de memoria no sería tal vez posible el advenimiento de otra cosa, distinta de lo que hay, pero también de lo que la memoria resguarda de su pérdida.

Carmen y Diego provocaron la utilización de “El ángel de la barricada", o el Engelshut de Paul Klee como identidad de nuestra escuela. Con su imagen recreada nos sumamos a resaltar la diferencia con el Angelus Novus, o ángel de la historia para Walter Benjamin. Y es que este ángel "no tiene su rostro vuelto hacia el pasado, ni las alas desplegadas por la tempestad del progreso, ni la expresión desencajada por la ruina y por la muerte que se acumulan a sus pies".

Este ángel "revoca las soledades que la adversidad destina a los rebeldes - aunque tal vez no su vida breve - y establece una comunidad ubicua entre los vivos, los muertos y los no nacidos". Habría que reescribirlo así - nos dicen ellos-:

Hay un cuadro de Paul Klee que se llama Engelshut. En él está representado un ángel que se despliega en la historia y el porvenir, un ángel de invención y de memoria, un ángel multitud que camina de manera tranquila y firme sin que nos sea dado saber hacia dónde. Un ángel que asiste a los que no se cansaron. No está desencajado sino multiplicado. No mira hacia el pasado ni hacia el futuro sino en torno, hacia donde estamos, como si buscara compañeros y con ellos y ellas empezar siempre de nuevo. Son los rostros del pasado en el corazón del presente, vueltos hacia los que continúan la obra emancipatoria que retoña una y otra vez para romper la piedra. Tiene las alas desplegadas como si 
quisiera con ellas dar cobijo a las generaciones e impulsarlas otra vez a la acción. El ángel de la barricada debe tener ese aspecto...

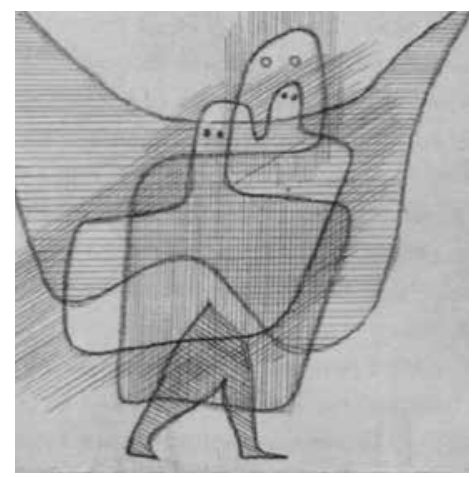

Fig. 1: In Engelshut, (Klee, 1931)

Gracias a Carmen y a todos los que ayudan a pensar en las barricadas, en las revueltas, las revoluciones, a su rotundo "Aún estamos vivos", por sugerirnos recrear el Engelshut de Klee y devolverlo como El ángel de la Revolución latinoamericana y caribeña.

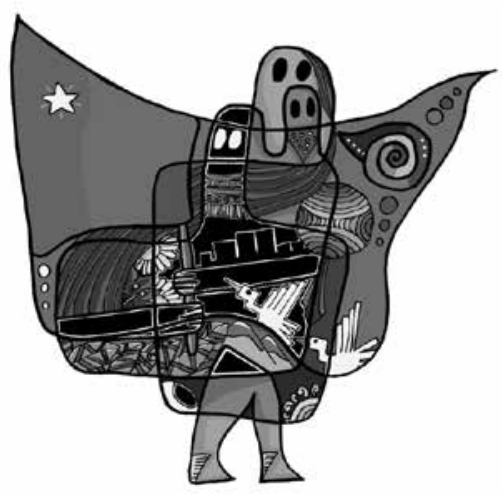





\section{Hay que crear una nueva legalidad*}

\section{Miguel Enríquez}

Nos hemos reunido hoy para rendir homenaje a la primera república socialista de América: la Cuba Revolucionaria. Un homenaje a la Revolución cubana hoy en Chile solo puede hacerse destacando las lecciones que nos entrega y en referencia a los logros, avances y dificultades que el proceso de la Revolución chilena encuentra en este instante, proceso que recién comienzan los trabajadores hoy en Chile.

La Revolución cubana es revolución, y la saludamos hoy aquí porque golpeó implacablemente a los dueños del poder y la riqueza y porque puso ese poder y riqueza al servicio de los intereses

* Fragmento del discurso de Miguel Enríquez, Secretario General del MIR, pronunciado en la Comuna de San Miguel en homenaje a la Revolución Cubana el 26 de julio de 1971. Fue publicado en Punto Final $\mathrm{N}^{\circ} 136.3$ de agosto de $19 \mathrm{C} 71$ 
de los trabajadores del campo y la ciudad. La Revolución cubana es revolución porque golpeó, denunció, destruyó y aplastó el poder norteamericano en Cuba. Es revolución porque comprendió que no se pueden hacer revoluciones hoy en el mundo sin entrar a enfrentar y combatir al imperialismo norteamericano. No se limitó a cambiar el régimen de propiedad jurídica; no se limitó simplemente a cambiar de propietario las empresas norteamericanas que había en Cuba sino que, además, denunció al imperialismo como el principal enemigo de los trabajadores del mundo; además llamó al pueblo, a los dos mil millones de humillados y ofendidos del mundo, no solamente de Cuba, a combatir al principal enemigo de los trabajadores, el imperialismo norteamericano.

“Solo es revolución la que denuncia y combate como enemigos del pueblo a los dueños de las empresas norteamericanas, de los bancos, de las fábricas y los fundos.

La Revolución cubana es revolución porque golpeó, destruyó y denunció a los dueños de los fundos, a los terratenientes que había en Cuba, a los dueños de la tierra, a los que explotaban a los campesinos. La Revolución cubana es revolución porque golpeó, destruyó, denunció y aplastó implacablemente a los dueños de las fábricas, a los que explotaban obreros en Cuba. La Revolución cubana es una revolución de verdad, porque golpeó y denunció a los dueños de los bancos, porque golpeó y destruyó la propiedad sobre los bancos privados, porque avanzó por el camino destruyendo enemigos, golpeando enemigos y mostrando enemigos.

Es revolucionario el proceso cubano porque hizo propiedad de todo el pueblo la tierra, porque entregó a los campesinos la tierra, no de algunos fundos, sino de todos los fundos. Entregó las fábricas a los obreros, no algunas fábricas, sino grandes fábricas a todos los obreros. Es revolucionario el proceso cubano porque 
entregó los bancos a la propiedad de todo el pueblo, porque hizo del pueblo cubano dueño de todas las fábricas, todos los fundos y todos los bancos.

De la Revolución cubana debemos aprender lecciones. Es la única revolución que se ha hecho en América Latina. Es la vanguardia hoy en América Latina y es la primera república socialista de América. Y es revolución porque comprendió que solo puede hacerse una revolución en el mundo, una revolución en América, solo si se golpea al enemigo; no solo si se le quita la propiedad sobre los medios de producción sino también si destruye su propiedad, si denuncia al mundo la explotación imperialista de los países de América, si al mismo tiempo llama al mundo entero al camino de la revolución. Si le muestra al mundo, como habría que hacerlo en Chile, que una revolución comienza hoy en Chile y ese es el camino de todo el pueblo, de toda América, de toda América Latina, y de Chile también.

Solo es revolución la que enfrenta y combate públicamente, la que denuncia a los yanquis, la que denuncia como enemigos del pueblo a los dueños de las fábricas, a los dueños de los fundos, a los dueños de los bancos.

Solo destruyendo la legalidad y las instituciones que impidan el avance de los trabajadores puede avanzarse en el camino de la Revolución.

Pero para hacer una revolución en Cuba no bastó exclusivamente la intención, no bastó solamente denunciar, no bastó solamente pronunciar cuál era el camino del pueblo cubano, sino que la Revolución cubana, al mismo tiempo su dirección, Fidel Castro y el Partido Comunista Cubano, fueron destruyendo la legalidad, las ataduras que el sistema tenía. Para poder avanzar el pueblo, para poder construir el socialismo, fueron avanzando y 
caminando al mismo tiempo que iban destruyendo todas las ataduras, toda la legalidad, todo el sistema que era anterior a ellos. Ese fue el camino de la revolución, ese es el único camino en América, el único camino en Chile, el único camino en Cuba.

Cuando en Cuba se tomó el poder, todas las leyes, todas las instituciones, toda la justicia, todas las Fuerzas Armadas del régimen anterior estaban intactas. Existía un régimen anterior que era el que definía cuáles eran las relaciones, cuál era el camino, qué es lo que era legítimo y qué es lo que era ilegítimo.

Los revolucionarios cubanos no solo fueron golpeando a los enemigos, no solo fueron caminando por el camino de la revolución. Los revolucionarios cubanos fueron rompiendo y destruyendo todas las ataduras que impedían el avance del pueblo, todo lo que impedía el camino de los trabajadores hacia el socialismo. Rompieron amarras, destruyeron limitaciones; barrieron con las barreras que les impedían avanzar; rompieron y crearon nuevas leyes; las leyes que les impedían avanzar fueron destruidas y aniquiladas. Toda muralla, todo obstáculo al avance de los trabajadores fue roto, fue pasado a llevar. La Revolución cubana sabía adónde iba, sabía lo que tenía que hacer y rompió toda muralla que se le puso en el camino. Nada podía impedir en Cuba el avance de los trabajadores, el avance del pueblo. Sabían los revolucionarios cubanos que las leyes, las instituciones, todo lo que heredaron del régimen anterior fue construido por los dueños de los fundos y las fábricas, fue construido por los norteamericanos, fue construido por los que vivían del goce del privilegio y la riqueza. Sabían los revolucionarios cubanos que todo el régimen, todas las leyes, todas las instituciones fueron construidas para defender la riqueza de unos pocos. Sabían que todas las leyes, todas las instituciones, todo lo que era el régimen legal y jurídico en Cuba, estaba construido para oprimir al pueblo, para explotarlo, para 
mantenerlo en la miseria, para que unos pocos gozaran de la riqueza a costa de muchos que trabajaban. Por eso, destruyeron las instituciones del régimen anterior y crearon nuevas, al servicio del pueblo, al servicio de los trabajadores. Destruyeron el Estado, destruyeron las leyes; construyeron nuevas leyes, construyeron un nuevo Estado, nuevas Fuerzas Armadas, construyeron nuevas instituciones, que se pusieron al servicio del avance de los trabajadores. Crearon un nuevo Estado. La justicia, el Estado y la legalidad de los revolucionarios. La justicia, el Estado y la legalidad de los trabajadores. Solo así se pudo hacer una revolución, destruyendo la ley que había sustentado la riqueza de unos pocos, destruyendo las instituciones que amparaban el lujo y los privilegios de unos pocos, creando otras nuevas, creando los caminos que los trabajadores necesitaban para hacer una revolución. Solo así se hacen revoluciones en el mundo y en América. Solo así es posible hacer revoluciones en Chile, en Cuba, en Vietnam, en China o en la Unión Soviética. Solo destruyendo las limitaciones al avance de los trabajadores, puede avanzarse en el camino de la revolución. Los trabajadores realmente terminarán con el régimen de explotación cuando destruyan todo lo que los limite, todo lo que los frene, todo lo que impida su avance. Eso es lo que debemos aprender de Cuba. Esas son las lecciones de la Revolución cubana; por eso Cuba es una Revolución; por eso Cuba es la vanguardia de los movimientos revolucionarios de América Latina; por eso Cuba es atacada; por eso Cuba sufre el cerco económico del imperialismo; por eso Cuba es combatida; por eso Cuba tiene que defenderse del imperialismo y de las agresiones; por eso respetamos a Cuba, por eso saludamos a Cuba, por eso hoy día rendimos un homenaje a Cuba.

Cuba no es solamente otra revolución; Cuba no es solo una isla que está alejada de nosotros; Cuba es un ejemplo que los 
trabajadores, los obreros, los campesinos, los pobladores y los estudiantes quieren seguir, se disponen a seguir y seguirán por todos los medios... Romperán los trabajadores chilenos todos los obstáculos que se les opongan al avance de ellos, todos los obstáculos que se les pongan por delante.

Lo fundamental del 4 de septiembre en adelante es la capacidad de iniciativa y movilización ganada por los trabajadores.

Como dijimos, no es posible hoy en Chile saludar a la Revolución cubana, hacer ningún tipo de homenaje a la Revolución cubana, si no nos referimos al proceso revolucionario que recién comienza en Chile. No es posible hablar de Cuba sin hablar de Chile hoy. 


\section{Historias desencadenadas ${ }^{*}$}

\section{Carmen Castillo}

La herencia no está precedida

por ningún testamento.

René Char

Acontece que Miguel aparece de improvisto. Estoy tan contenta de verlo. Regresa de un más allá, o regresa, simplemente. En la aurora que despunta entre las cimas redondas y boscosas de los Alpes, sobre Grasse, bordeando la ruta napoleónica, lo veo entrar en el amplio patio delantero de la antigua casa que ahora me acoge. Lo veo, a pocos metros, rodeado de compañeros y algunas compañeras. No puede evitarme cuando me acerco, pero se niega a toda proximidad. Sé que algo le ha molestado, algo que puede ser cualquier cosa que atente a la fidelidad de la promesa hecha. Intento aclarar qué he dejado de cumplir. Pero nunca lo logro. Cada vez, en cada aparición, cualquiera sea el contexto, sucede lo mismo, su rechazo, su distancia, que no logro sobrepasar, mi imposibilidad de hablar, de murmurar algo, ¿qué? No tengo las

* Prólogo al libro de Marco Álvarez Vergara Miguel Enríquez. Mi felicidad es la lucha, en proceso de edición. 
palabras. Nunca las encuentro. Cuando lo vuelvo a intentar, unos días después, ahora en la arena negra frente al oleaje en la desembocadura del Bío Bío, su rostro vibra de una alegría profunda, su mirada fija algo, a lo lejos, más allá del objetivo de la cámara fotográfica de su amigo Bautista Van Schowen. La belleza del horizonte lo atrapa y lo conmueve. Solo entonces comienzan a dibujarse esos espacios-tiempos no rememorados, no trabajados, no recreados en relatos o en historia.

“La herencia no está presidida por ningún testamento", extraño aforismo, dice Hannah Arendt, la de este verso del poeta René Char. Este escribe cuando sus vivencias de combatiente en la Resistencia francesa contra el fascismo se alejan. Anticipa lo que va a suceder: "Si logro escapar, sé que deberé romper con el aroma de esos años esenciales, rechazar, no reprimir, silenciosamente lejos de mí mi tesoro".

Durante ese tiempo de lucha, el trabajo político unía la palabra y el acto. Cada instante era vivido como si fuera el último. No había espacio para "el espesor triste de una vida privada centrada en nada sino en ella misma". La realidad era tangible, instantánea, total, y concernía al ser junto a los otros, un "nosotros". Esa eternidad se esfuma inexorablemente al alejarse la experiencia vital de ese compromiso político.

“Así, perdimos nuestro tesoro".

Es a la ausencia de un nombre para designar el tesoro perdido a lo que el poeta alude cuando escribe que nuestra herencia no está presidida por ningún testamento, señala la lectura de Hannah Arendt. Un testamento que le dice al heredero lo que será legítimamente suyo, que le asigna un pasado al futuro. “ $\mathrm{Y}$ sin tradición que escoge y nombra, que transmite y conserva, que indica dónde se encuentran los tesoros y cuáles son sus valores, 
pareciera que ninguna continuidad en el tiempo ha sido asignada". El tesoro fue perdido no por las circunstancias históricas ni la mala suerte, sino porque ninguna tradición había previsto su venida o su realidad, porque ningún testamento lo había legado al futuro. “La tragedia comenzó cuando se constató que no había ninguna conciencia para heredar y cuestionar, meditar y recordar", interpreta Arendt. El punto central es que el "término" del acontecimiento "cumplido" no alcanzó la conciencia de los que estaban llamados a contar la historia y a transmitirle su sentido; y sin este finiquito del pensamiento después del acto, sin la articulación lograda por el recuerdo, no quedaba simplemente ninguna historia que pudiese ser contada (Castillo, 1972) ${ }^{1}$.

Esta visión de una herencia imposible de nombrar me estremece. ¿Tiene esto algo que ver con la liviandad que durante tanto tiempo me mantuvo distanciada de la búsqueda de un objeto, un baúl, que contenía fragmentos de aquel tesoro extraviado, búsqueda que hubiera debido revelar parte de los documentos descuidados, arrumbados, que esta antología de textos inéditos del joven Miguel Enríquez, seleccionada por Marco Álvarez, reúne en este libro?

No lo sé, pero tal vez al intentar contar esta historia de un baúl olvidado y finalmente reencontrado pueda aclarar en algo tamaño absurdo. "Locura, mi amor, esta carencia de memoria, esta monstruosa liviandad que me habita", escribí hace mucho tiempo en Ligne de fuite (Castillo, 1978) ${ }^{2}$.

1 Castillo, C. (1972). La crise de la culture. Huit exercices de pensée politique, París : Gallimard.

2 Castillo, C. (1988). Ligne de fuite. París : Barrault. 
Érase una vez, ¿en otro tiempo, en otro mundo?, un golpe de Estado. Chile, 11 de septiembre de 1973. Las fuerzas armadas detienen, torturan, matan a todos aquellos que aspiran y luchan por una sociedad de justicia social y de libertad. Necesitan aplastar, quebrar en mil pedazos ese Nosotros en comunión. Para extirpar el alma que amenazaba, más allá de los cuerpos abatidos, pretendieron arrasar, destruir todo aquello que nutría aquel espíritu revolucionario. En las esquinas, en las veredas de las ciudades, en los poblados del campo, el fuego consumía libros, revistas, documentos, afiches, discos... Esas fogatas, custodiadas por oficiales y soldados hilarantes, convencidos de que de las cenizas nada podría resurgir, atemorizaron, y era normal, a las personas que se sabían en peligro por poseer las canciones de Víctor Jara o Violeta Parra, los poemas de Neruda o de Gonzalo Rojas, los himnos de la Unidad Popular interpretados por Quilapayún, Inti Illimani, los Illapu... Las ediciones de la editorial Quimantú, cualquier folleto sobre la Revolución cubana... La ignorancia de los represores condujo a excesos insospechados y poco a poco todo libro, todo papel, toda palabra, se convertía en peligrosa... Para preservar la vida teníamos que proceder a destruir nuestras pertenencias, con extrema discreción, también nosotros, los perseguidos.

En los primeros días, luego de levantarse el toque de queda, entre la urgencia de los actos y las decisiones que la clandestinidad exigía, Miguel me designó una tarea. Preservar documentos y libros era para él primordial. Fue así como me pidió encontrarles refugios seguros. Luego de una severa selección de aquellas lecturas indispensables para definir el nuevo período histórico que se abría en Chile (cambiando las tapas peligrosas por otras de novelas populares), organizó y ordenó diversos documentos manuscritos o tecleados a máquina en hojas finas, cuadernos, cartas en cajas y repletó maletas con libros de su biblioteca, libros que 
lo acompañaron de casa en casa desde Concepción a Santiago. Realicé varios traslados. Creo que aún circulaba en el Fiat 500, manejando de un punto de contacto a otro, con aquellos preciados paquetes, aparentemente sin miedo, pero con el ceño fruncido y las mandíbulas tensas.

Ya no recuerdo con precisión, tierras perdidas de la memoria, los lugares ni las personas esenciales en esta cadena de solidaridades para salvarlos del fuego. De la bruma aparece el estacionamiento del colegio Santiago College o el garaje de una casona en el barrio Ñuñoa, pero no sé las razones exactas que me condujeron a esos puntos. Hoy solo veo con nitidez la sonrisa amplia y los gestos firmes de mi madre, Mónica, pequeña silueta fina, abriendo la puerta de su auto, ¿qué marca?, y ayudándome a trasladar los pesados bultos. Una parte de los libros marxistas serán acogidos en los sobrecargados y empolvados libreros de la casa de Jaime Castillo Velasco, quien se irguió desde los primeros días como defensor de los detenidos militantes del MIR, que ni siquiera Amnistía Internacional aceptaba incluir en sus listados, al inicio, por ser considerados terroristas. Con su tierna ironía de siempre, Jaime aceptó custodiar la biblioteca de un contundente disidente del régimen de Stalin y de la URSS de los procesos de Moscú, su pesadilla. En su casa de Simón Bolívar, allanada, defendió la colección de escritos de Lenin y Trotsky con orgullo. No fueron movidos en sus períodos de exilio en Caracas y allí permanecieron hasta su muerte en 2002.

Mónica, por su lado, segura de sí misma, sin temor, empujada por la insolencia de su carácter y de su clase social, desempacó los documentos en su casa, y la leyenda cuenta que los metió en un viejo baúl originario de la hacienda de don Eliodoro Yánez, su abuelo. Enterró el baúl en la estructura de cemento en forma de sofá, situada entre un árbol, plantado a un costado, y una mesa de 
ping-pong, en la amplia sala de estar de la casa que mi padre, el arquitecto modernista, acababa de construir en el fondo de la antigua quinta de Los Guindos. Allí permanecieron estos “elementos" solitarios, hilachas de un pasado hundido bajo el cuero, la madera, el cemento y los cómodos cojines grises y negros sobre los cuales se sentaron los convives frente a la chimenea de cobre durante años y años. La familia partió al exilio el 11 de septiembre del 74, regresó a fines de los setenta, participó activamente en la resistencia de los ochenta, acogió escéptica a la democracia de los noventa y a comienzos del siglo xxi decidió dejar ese lugar y mudarse a un departamento. Abrieron un hoyo en la pared colindante con el edificio y realizaron la mudanza. Al desarmar ese largo mueble de cemento apareció el baúl. Era el mes de septiembre de 2003, treinta años después de haber sido escondido.

Habiéndoseme confiado, en el origen de la cadena, cuidar estos documentos, ¿qué muro invisible se levantó entre su existencia y la mía?

El tesoro perdido de nuestro devenir militante lo percibo a través del texto de Hannah Arendt, sin embargo, quisiera detenerme un momento en la desmemoria.

“Hay golpes tan fuertes en la vida... yo no sé”, escribe César Vallejo. Solo los recuerdos, que nunca envejecen, de los hechos que condujeron a la muerte de Miguel permanecieron en mí intactos. Habitaron todo el espacio de mi mente. La desesperación me embargó desde el atardecer de ese 5 de octubre. Miguel no llevaba la muerte en sí mismo, todo en él era músculo y flexibilidad y sentidos, y podría haber enumerado una larga lista de proyectos, todos sensatos. La muerte provino de una voluntad extranjera a su cuerpo, a su vida. Tuvieron que pasar por mí las horas, miles y miles de horas, en ese estado de suspensión de la existencia. Y luego en ese estado de fuga, sin meditar, sin reflexionar, 
tratando de recordar cómo se hace para recordar. Pero, ¿recordar qué? No lo sabía.

Luego de la sideración, intenté darle forma a aquel mensaje de Miguel. La muerte no es un asunto de los revolucionarios, los revolucionarios aman la vida porque la vida los ama. Escribí entonces, a fines de los setenta, el libro Un día de octubre en Santiago y luego me desentendí de todo trabajo en torno a una herencia que no me estaba destinada. Cada cual era libre de ir a recoger en el legado aquello que lo ayudara a vivir. Cuando por su propia fuerza la realidad volvió a imponerse y otra vida comenzó a ser vivida, y que recuerdos recientes fueron sumergiendo a los antiguos, la desmemoria fue una comodidad.

Lo que hoy me remece, me cuestiona, es cómo continué ignorando ese baúl durante los cinco años de rodajes, entrevistas, vivencias, montaje, búsqueda de archivos, que dieron forma a la película Calle Santa Fe. Mónica, en nuestras conversaciones por teléfono casi cotidianas, me contó su asombro cuando lo redescubrió al realizar la mudanza al nuevo departamento. Lo desenterró y le entregó su contenido a aquel que encarnaba la representación del MIR, Andrés Pascal Allende. Pensé que era lo conveniente, no me sentía concernida. Hoy me digo que podría, al menos, haber tenido la curiosidad de ir a ver, tocar, lo que allí había sido salvado del fuego, pues la intención en ese trabajo fílmico era no una biografía de Miguel, pero sí un esbozo de la militancia del MIR a lo largo de su corta historia. Pues no. No busqué conocer lo que contenía aquel “barretín” emergido del cemento, ni siquiera cuando Andrés se refirió a él en un artículo de prensa en 2004. Actué como si nunca hubiera tenido nada que ver con esta decisión de Miguel de salvar de la destrucción la historia, las huellas de las experiencias de la organización. No reflexioné, no estudié, no guardé, no cuidé. Fallé en esa cita entre el antaño y el ahora. 
La herencia no tiene destinatario y la mujer que recibió la misión de preservar ese legado ya no existe. La que le siguió tomó bifurcaciones que vibraban a veces al unísono con ese pasado ardiente, pretendió amar aquellos instantes cuando el viento arrastra nubes que vienen de lejos, densas de fantasmas que envuelven, encantan, pero no para hundir nuestros frágiles cuerpos bajo una carga pesada, pues ninguna experiencia está terminada, archivada, sino para impulsarnos hacia nuevas destinaciones. “La deuda contraída con el pasado abre la promesa de una redención posible", una línea de horizonte. Y, sin embargo, ella esquivó, ignoró el baúl y su contenido.

Hubo que esperar el trabajo paciente y riguroso del joven historiador Marco Álvarez para que al fin mi mirada se detuviera en estos documentos. Me obligó a prestarles atención. Su decisión de realizar una selección para este libro y la solidaridad irrestricta de Sebastián Barros y la editorial Pehuén permiten el inicio de su libre circulación. Esa voluntad de difundirlos me condujo, finalmente, este año, a tomar entre mis manos los cuadernos personales del joven Miguel Enríquez (algunos fragmentos son publicados en este libro). Hoy se encuentran en proceso de restauración, gracias al trabajo riguroso y delicado de Marcela Candía. En el momento de descubrirlos, ver el deterioro producido por hongos y humedades durante ese largo tiempo de abandono, agujeros, manchas negras, tinta borroneada, hojas pegadas, se reabrió la herida de mi tardía toma de conciencia.

Nadie me ha pedido rendir cuentas, sola busco comprender. Aún no lo logro, sin embargo, esa brecha entre el pasado y el presente a la cual se refiere Hannah Arendt me permite, al menos, abrir una pista para reflexionar: se perdió el tesoro, pues no supimos nombrarlo, y con él se rompió el hilo, el delicado tejido que entrelazaba nuestras acciones a ideas revolucionarias que nos habían 
forjado en la juventud y acompañado a lo largo de nuestras vidas, con altos y bajos, a veces brasas ardientes, a veces cenizas apenas tibias, andamios de nuestra visión política, aquella que Miguel comenzó a pensar y también a anotar desde la adolescencia y durante todos sus años de formación política. Un intelectual revolucionario, que vislumbró temprano que por allí iba la cuestión de la libertad en actos, de aquello que denominó "Mi felicidad es la lucha". La felicidad se da cuando la gente puede entregarse por completo al momento que está viviendo, cuando ser y llegar a ser son la misma cosa" (Berger, 2011) ${ }^{3}$.

Una cita de John Berger, regalo de Diego Tatián, filósofo argentino. Un encuentro decisivo. Cada vez que se despierta el deseo de aportar algo en algún taller, exposición o texto, surge un escritor para guiarme. Esta vez, al iniciar la escritura de este prólogo, y gracias al enriquecedor diálogo con mi amiga cineasta Macarena Aguiló, leo con emoción un texto, "El ángel de la barricada”, y todo se ilumina. Diego expresa de manera contundente mi sentir y la belleza de su escritura da claridad a una manera de pensar y actualizar nuestra memoria que me parece importante compartir. Con él, entonces, concluyo:

Hay un punto exacto, aunque imprevisible, en el que la historia y la naturaleza forman una encrucijada, la encrucijada de la que irrumpen las rebeliones humanas. Abatimiento y levantamiento establecen los términos del campo de tensiones en el que transcurre la historia, en la que se atesora aún la pregunta por el dolor y la felicidad.

3 Berger, J. (2011). Cumplir con una cita, México: Universidad del Claustro de Sor Juana, Era., p. 210. (El destacado es corresponde a la autora). 
(...) Ni las luchas sociales -que suceden sin estar sometidas a cálculo ni costo de pérdidas, simplemente suceden- ni la temporalidad en la que se inscriben tienen en sí mismas un sentido -que solo el arte, el pensamiento y la narración política son capaces de procurarles. “Todas las penas pueden soportarse si las ponemos en una narración o contamos una historia sobre ellas" es una frase de Isak Dinesen que le gustaba mucho a Hannah Arendt. ${ }^{4}$ Lo insoportable no es el dolor en sí, sino el sinsentido en el que queda capturado cuando ese dolor no es capaz de sobreponerse a él (es decir, cuando se reduce a puro "sufrimiento"). Si acaso es necesario abdicar de la Historia en su acepción más altisonante, no así de la solidaridad ética y teórica con el dolor humano y con las luchas sociales que nacen de su existencia; ni de la acción política que no abjura de las revueltas, aunque deparen una brevedad a la vida rebelde; ni de la tarea de relatarlas después y hacer algo con ellas, para no abandonarlas al sinsentido.

La memoria de las rebeliones reviste un inmediato significado político: reinscribirlas en una narración traducible y hacer con ellas una ofrenda de sentido - no para la repetición sino para la disrupción y para la invención. Sin esa acción de memoria no sería tal vez posible el advenimiento de otra cosa, distinta de lo que hay, pero también de lo que la memoria resguarda de su pérdida. El ángel de la barricada es diferente del ángel de la historia [el de Walter Benjamin ${ }^{5}$ ]: no tiene su rostro vuelto hacia el pasado, ni las alas desplegadas por la tempestad del progreso, ni la expresión desencajada por la ruina y por la muerte

4 Arendt, H. (1993). La condición humana, Barcelona: Paidós p. 199.

5 Lowy, M. (2002). Aviso de incendio, Buenos Aires: Fondo de Cultura Económica. [Comentario y nota de la autora]. 
que se acumulan a sus pies. El ángel de la barricada revoca las soledades que la adversidad destina a los rebeldes -aunque tal vez no su vida breve- y establece una comunidad ubicua entre los vivos, los muertos y los no nacidos. Podríamos reescribirlo así: Hay un cuadro de Paul Klee que se llama Engelshut. En él está representado un ángel que se despliega en la historia y el porvenir, un ángel de invención y de memoria, un ángel multitud que camina de manera tranquila y firme sin que nos sea dado saber hacia dónde. Un ángel que asiste a los que no se cansaron. No está desencajado sino multiplicado. No mira hacia el pasado ni hacia el futuro sino en torno, hacia donde estás, como si buscara compañeros y con ellos y ellas empezar siempre de nuevo. Son los rostros del pasado en el corazón del presente, vueltos hacia los que continúan la obra emancipatoria que retoña una y otra vez para romper la piedra. Tiene las alas desplegadas como si quisiera con ellas dar cobijo a las generaciones e impulsarlas otra vez a la acción. El ángel de la barricada debe tener ese aspecto...

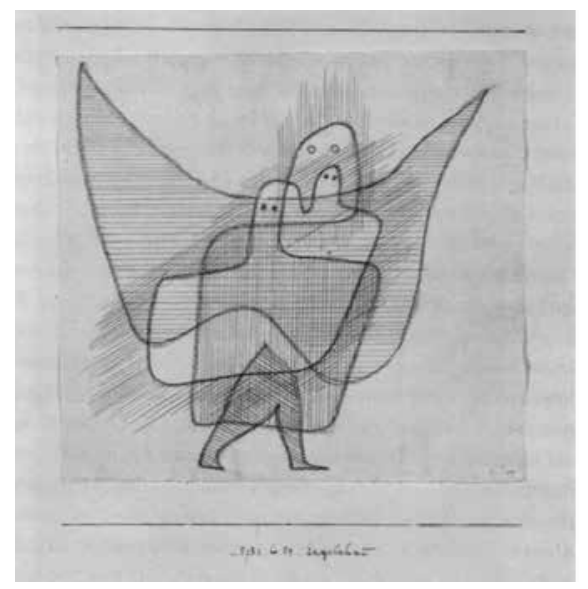

Fig. 3: In Engelshut, (Klee, 1931) 
La indagación de una fraternidad posible cuando la Historia deja su lugar a las historias que las rebeliones desencadenan es acaso la tarea de una política que no se desentiende de una promesa de felicidad común y mantiene abierta la pregunta que la inquiere. (...) la pregunta por la rebelión, que (...) reemprende su obra sin cálculo una y otra vez, cuanto menos para que los hombres y mujeres del porvenir no carezcan de una memoria a la que recurrir en momentos de adversidad, si fuera el caso de hallarse condenados a vivir y resistir sin "esperanza en el pasado" -según una expresión paradójica que puede tal vez significar: no solo pensar el pasado sino sobre todo dejarnos pensar por él. Y alojar en el trabajo político la potencia imprevisible de su anacronía (pues “los muertos no se quedan nunca donde los enterraron"), abiertos a la acción de una memoria involuntaria común que, en "momentos de peligro", desencadena en el "cerebro de los vivos" el cúmulo inmemorial de las luchas sociales atesoradas por la historia (Tatián, 2019) ${ }^{6}$.

6 Tatián, D. (2019) El ángel de la barricada., Haroldo, Revista del Centro Cultural de la Memoria Haroldo Conti, 12 de junio, recuperado de https://revistaharoldo.com.ar 


\section{Vestimenta étnica para un "genocidio" político*}

\section{Adrián Zapata}

\section{La tragedia guatemalteca durante el conflicto armado interno}

No hay conducta criminal más deleznable que la que niega la diversidad de la humanidad, calidad que es inherente a su naturaleza, perversa pretensión que persigue la comisión del delito de genocidio. Su perpetración no está necesariamente ligada a la magnitud cuantitativa del daño causado, sino a la intencionalidad que lo motiva, mens rea (mente culpable, intencionalidad), como dirían los juristas. Lo fundamental es, por lo tanto, lo que el sindicado de cometer un delito estaba pensando y, por consiguiente, la

* Texto tomado de la Revista Análisis de la Realidad Nacional, Año 7 Edición 133 - enero / 2018 
intención que tenía con dicha conducta delictiva. La esencialidad de su tipificación está ligada a la subjetividad del perpetrador.

El genocidio es el crimen de los crímenes aunque, junto a los crímenes de guerra y los de lesa humanidad, constituyen lo que se

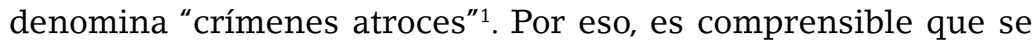
tienda a identificar la barbarie ocurrida en Guatemala durante el conflicto armado interno como genocidio. En el período de la guerra interna, según la Comisión del Esclarecimiento Histórico $(\mathrm{CEH})$, el número de personas desaparecidas o asesinadas fue de más de doscientas mil, habiendo registrado la Comisión cuarenta y dos mil doscientas setenta y cinco víctimas, incluyendo hombres, mujeres y niños, de las cuales veintitrés mil seiscientas setenta y una fueron ejecuciones arbitrarias y seis mil ciento cincuenta y nueve desapariciones forzadas, 83\% de ellas de personas de origen maya. El Estado fue responsable del 93\% sobre el total de casos investigados por la CEH (1999). Para la población maya, que constituye la mayoría de habitantes del altiplano occidental del país, donde la guerrilla tenía amplia base social y política, los peores años fueron de 1981 a 1983.

Según dicho informe, entre quinientas mil y un millón de personas fueron desplazadas de sus lugares de vivienda, debido a la represión estatal. Se estima que 150 mil buscaron refugio en México (un tercio de las cuales se ubicaron en campamentos

1 El término "crímenes atroces" se refiere a tres crímenes internacionales definidos jurídicamente: genocidio, crímenes de lesa humanidad y crímenes de guerra. Las definiciones de los crímenes pueden encontrarse en la Convención para la Prevención y la Sanción del Delito de Genocidio de 1948, los Convenios de Ginebra de 1949 y sus Protocolos Adicionales de 1972 y el Estatuto de Roma de la Corte Penal Internacional de 1998, entre otros tratados (ONU, 2014). 
a cargo del Alto Comisionado de Naciones Unidas para los Refugiados, ACNUR) (CEH, 1999). Además, de acuerdo a datos reportados por la Agencia de Prensa alternativa CERIGUA, aproximadamente cuatrocientas cuarenta aldeas fueron desaparecidas en ese período.

Es imposible, por lo tanto, que deje de haber indignación, nacional e internacional, ante lo ocurrido, sentimiento que se expresa en entender como horrenda la experiencia vivida por el pueblo guatemalteco, especialmente por la población indígena. Deducir, por consiguiente, que en Guatemala hubo genocidio, parece ser comprensible; el drama colectivo vivido es fácilmente equiparable a un "crimen de crímenes".

\section{El delito de genocidio}

La conciencia mundial surgida después de las atrocidades cometidas durante la Segunda Guerra Mundial, dirigidas a la destrucción de determinados grupos sociales, llevó a que en la primera Asamblea General de las Naciones Unidas, en 1946, se emitiera una resolución, la 96 (I) (11 de diciembre), que se refiere a dicho tema y que dice:

El crimen de genocidio (...) Muchos ejemplos de tales crímenes de genocidio han ocurrido cuando grupos raciales, religiosos o políticos han sido destruidos parcial o totalmente (...) La Asamblea General, por lo tanto, afirma que el genocidio es un crimen del Derecho Internacional que el mundo civilizado condena y por el cual los autores y sus cómplices deberán ser castigados, ya sean estos individuos particulares, funcionarios públicos o estadistas, y el crimen que hayan cometido sea por motivos religiosos, raciales o políticos, o de cualquier otra naturaleza (ONU, 1946). 
Dos años después, el 9 de diciembre de 1948, en las Naciones Unidas se aprueba la Convención para la prevención y la sanción del delito de genocidio, que en sus párrafos sustanciales prescribe lo siguiente:

Las partes contratantes, considerando que la Asamblea General de las Naciones Unidas, por su resolución 96 (I) del 11 de diciembre de 1946, ha declarado que genocidio es un delito de derecho internacional contrario al espíritu y a los fines de las Naciones Unidas y que el mundo civilizado condena; reconociendo que en todos los períodos de la historia el genocidio ha infligido grandes pérdidas a la humanidad; convencidas de que para liberar a la humanidad de un flagelo tan odioso se necesita la cooperación internacional; convienen en lo siguiente:

Artículo II. En la presente Convención, se entiende por genocidio cualquiera de los actos mencionados a continuación, perpetrados con la intención de destruir, total o parcialmente, a un grupo nacional, étnico, racial o religioso, como tal: a) Matanza de miembros del grupo; b) Lesión grave a la integridad física o mental de los miembros del grupo; c) Sometimiento intencional del grupo a condiciones de existencia que hayan de acarrear su destrucción física, total o parcial; d) Medidas destinadas a impedir los nacimientos en el seno del grupo; e) Traslado por fuerza de niños del grupo a otro grupo.

Adicionalmente, también hay referencia a este delito en el Estatuto de Roma que crea la Corte Penal Internacional (1998), además de la Convención sobre la imprescriptibilidad de los Crímenes de Guerra y de los Crímenes de Lesa Humanidad (1968).

Como se puede observar, existe una diferencia fundamental entre lo planteado en la resolución 96(I) de 1946 y la tipificación 
que se hace por Naciones Unidas dos años después, ya que la primera dice textualmente “(...) el crimen que hayan cometido sea por motivos religiosos, raciales o políticos, o de cualquier otra naturaleza.", mientras que la segunda establece “(...) destruir, total o parcialmente, a un grupo nacional, étnico, racial o religioso, como tal".

Para efectos del presente artículo nos interesa resaltar la ausencia de motivaciones políticas o de otra naturaleza en la tipificación del delito que finalmente se aprobó.

En el ámbito nacional, el artículo 376 del Código Penal retoma las definiciones internacionales referidas y establece que:

Comete delito de genocidio quien, con el propósito de destruir total o parcialmente un grupo nacional, étnico o religioso, efectuare cualquiera de los siguientes hechos: $1^{\circ}$. Muerte de miembros del grupo. $2^{\circ}$. Lesión que afecte gravemente la integridad física o mental de miembros del grupo. $3^{\circ}$. Sometimiento del grupo o de sus miembros a condiciones de existencia que pueda producir su destrucción física, total o parcial. $4^{\circ}$. Desplazamiento compulsivo de niños o adultos del grupo a otro grupo. $5^{\circ}$. Medidas destinadas a esterilizar a miembros del grupo o de cualquier otra manera impedir su reproducción. El responsable de genocidio será sancionado con prisión de treinta a cincuenta años (Congreso de la República, 1973, p. 61).

Como se observa, y ya lo han dicho otros autores, a este delito lo caracterizan básicamente tres elementos: 1) la intención (mens rea);2) lo que debe entenderse como grupo humano que se quiere eliminar; y 3) la lesión causada.

El “móvil”, diferenciándolo de mens rea, no es pertinente en la tipificación del delito, ya que lo esencial es la intención. De acuerdo al Diccionario de la Real Academia Española, "móvil" es "aquello 
que mueve material o moralmente algo", mientras que intención (que corresponde a mens rea), lo define como la "determinación de la voluntad en orden a un fin". Por esas y otras razones, coincidimos con quienes señalan que el móvil no puede ser parte de los elementos constitutivos de la tipificación de este delito.

Siempre en relación a mens rea, es pertinente citar a Valencia Villa cuando afirma que:

En relación con la intención de destruir, se establece que el propósito debe ser la destrucción del grupo como una entidad separada y distinta (Tribunal Penal para la antigua Yugoslavia, caso Blagojevic y Jokic, (Sala de Primera Instancia), 17 de enero de 2005, párr. 670). Aunque la destrucción no sea el objetivo principal, puede convertirse en el objetivo (Tribunal Penal para la antigua Yugoslavia, caso Krstic, (Sala de Primera Instancia), 2 de agosto de 2001, párr. 572.). Se requiere un ataque intencional contra un grupo y la intención de participar en él o de llevarlo a cabo (Tribunal Penal para la antigua Yugoslavia, caso Jelisic, (Sala de Primera Instancia), 14 de diciembre de 1999, párr. 78). No es suficiente el saber que el crimen original probablemente resultaría en destrucción, la destrucción debe ser el objetivo (Tribunal Penal para la antigua Yugoslavia, caso Blagojevic y Jokic, (Sala de Primera Instancia), 17 de enero de 2005, párr. 656) (Valencia Villa, 2013).

Lo fundamental, de acuerdo a los fallos citados por Valencia Villa, es el objetivo que se persigue (la destrucción del grupo), sea que dicho objetivo se persiguiera desde el principio o que se convierta en tal. El hecho de que se produzca la destrucción no es lo esencial.

Respecto de la definición de un grupo, este no puede ser ocasional o transitorio, debe ser permanente. 
Y con relación a los actos concretos mediante los cuales se expresa la intencionalidad, actus reus, como dirían los juristas, estos están claramente establecidos en el texto que tipifica dicho delito.

\section{El "genocidio" en Guatemala, en el contexto de la Guerra Fría}

Como ya se apuntó, la tragedia sufrida por el pueblo de Guatemala fue de tal magnitud y horror que es muy fácil que cualquier persona se incline por afirmar que fue un genocidio. Pero hay que tomar en cuenta que esta conclusión tiene implicaciones sociopolíticas e históricas significativas, que trascienden la sola dimensión jurídica, de por sí substancial.

Por eso, es importante tener presente la definición de genocidio ya mencionada, contenida en la Convención para la Prevención y Sanción del Delito de Genocidio de 1948, ratificada por el Estado de Guatemala en 1950, la cual especifica que dicho crimen hace referencia a "cualquiera de los actos perpetrados con la intención de destruir, total o parcialmente, a un grupo nacional, étnico, racial o religioso, como tal". La presión de la Unión Soviética hizo que esa definición no contuviera la referencia a grupos "políticos y de otra clase", elementos sustanciales que aparecían en la resolución 96 (I) de la Primera Asamblea General de la ONU, en 1946, porque no convenía a las prácticas estalinistas y, también, debido a la visión rígida que entonces tenían los Estados sobre el principio de la soberanía. Se argumentaba que al incluir las intenciones políticas podría alentarse la injerencia extranjera en asuntos internos de los Estados. 
Es de vital importancia tener presente que en Guatemala lo que hubo no fue una guerra étnica. El conflicto armado interno se dio en el marco de la Guerra Fría, bajo el impulso de la "guerra de baja intensidad", ambos conceptos propios de la estrategia geopolítica de Estados Unidos, que consideraban la defensa de su seguridad nacional más allá de sus fronteras.

El ejército guatemalteco, fiel a su subordinación al imperio, asumió plenamente la antipatriótica función de definir como "enemigo interno" a quienes libraban una lucha revolucionaria antioligárquica y antiimperialista.

Sin duda que en la conducta criminal del ejército guatemalteco había un grado relevante de racismo en su cúpula dirigente, pero esta, sin ánimo de justificar tan deleznable realidad, es una característica generalizada en la sociedad guatemalteca. Además, la formación ideológica de ese ejército, que se entregó a los Estados Unidos desde que abdicó a la defensa de la soberanía nacional en 1954, giró en torno al "anticomunismo", expresado como un odio hacia ese supuesto enemigo interno que cada vez se ampliaba más, incluyendo no solo a las fuerzas insurgentes sino también a su base social, real o imaginada por los altos mandos. Recordemos que "quitar el agua al pez" fue la consigna por medio de la cual se justificó la represión generalizada hacia la población que real o supuestamente apoyaba a la guerrilla.

Y esa conducta criminal no fueron actos aislados, se institucionalizó con la contrainsurgencia, pilar fundamental de la lucha política y militar del Estado en contra de la "subversión”.

El documento del ejército guatemalteco denominado "Plan de Operación Sofía", en el numeral III, al definir la Misión de dicha operación, claramente dice que el desplazamiento militar se realizaría para “iniciar operaciones antisubversivas ofensivas y 
operaciones psicológicas en el área de Operaciones Gumarcaj en coordinación con la mencionada Fuerza de Tarea, para darle mayor ímpetu a dichas operaciones y exterminar a los elementos subversivos en el área" (Ejército de Guatemala, 1982). Es explícita la intención de esa movilización, ya que se perseguía la exterminación de los subversivos.

O sea que dicha operación se definió como antisubversiva, con el objetivo explícito de exterminar la subversión en esa área.

En correspondencia con lo acá argumentado, es ilustrativo el material de URNG titulado “Balance de la situación del ejército enemigo", de fecha junio de 1985, el cual comienza diciendo que

La actual estructura orgánica del ejército guatemalteco fue diseñada en 1982 y se puso en práctica casi de inmediato, habiendo terminado su total implementación para mediados de 1983. Basándose en la doctrina militar contrainsurgente norteamericana, su concepción y diseño están encaminados a concentrar en una zona determinado número de efectivos, suficientes para controlarla militarmente y evitar o aniquilar, según sea el caso, cualquier presencia o actividad guerrillera (URNG, 1985).

URNG también hace referencia en ese documento a la estrategia de impulsar las Patrullas de Autodefensa Civil como parte de esta visión. Expresa al respecto que dicha estrategia fue

Concebida fundamentalmente para aislar por completo a la guerrilla de la población en general y de su base social en particular, y evitar así toda posibilidad de apoyo de la población a las fuerzas guerrilleras, este plan de gran envergadura empieza a ser implementado en el año 81, aunque es en el segundo semestre del 82 cuando se institucionaliza y se estructura, extendiéndose a partir de entonces sistemáticamente a todo el territorio nacional (URNG, 1985). 
Estaba muy claro para la organización insurgente que la barbarie que ocasionaba su enemigo estaba dirigida a aniquilar a la guerrilla y a aislarla de la población en general y de sus bases sociales: la población de los territorios donde ella actuaba.

Ahora bien, el accionar del ejército guatemalteco no se puede comprender al margen del contexto internacional en el cual se produjo, particularmente la Guerra Fría entonces imperante, y la decisión del poder hegemónico de uno de los polos de esta confrontación, los Estados Unidos de América, que desarrollaron los conceptos y estrategias correspondientes de Defensa Interna en el exterior y de los conflictos de baja intensidad, ambos intrínsecamente vinculados.

Estados Unidos asumió la tarea de "formar" y "capacitar" a los ejércitos donde hubiera un proceso de insurrección en marcha, teniendo como sede principal de este entrenamiento a la Escuela de las Américas del Ejército de los Estados Unidos, en el Fuerte Gulick, en Panamá. Un documento importante que muestra el cumplimiento de este objetivo es el Manual FM 100-20 del Cuartel General de la Secretaría del Ejército de EE.UU., fechado enero de 1981, traducido al español en 1982, precisamente en la Escuela de las Américas.

Allí se expresa lo que se entiende por Defensa Interna en el Exterior y por Conflictos de Baja Intensidad. Dicho manual establece que "La doctrina proporciona principios fundamentales cuyo propósito es guiar las acciones de las fuerzas militares que están empeñadas en llevar a cabo operaciones de Defensa y Desarrollo Internos", aunque el mismo manual aclara a sus destinatarios que " $\mathrm{Al}$ aplicar estos principios usted deberá percatarse de que la situación de cada país que se enfrenta a una insurrección es única en su género y muy propia de ese país", agregando que “(...) los principios de este manual proporcionan una guía 
general para llevar a cabo operaciones de defensa y desarrollo internos; usted deber usar su buen juicio al adaptarlos a cada situación en particular" (Ejército de EE. UU., 1981, énfasis propio).

De manera explícita, el manual dice que "Usted puede ver que cada participación del Ejército de EE.UU. en 'conflictos de baja intensidad' también se consideran como actividades de 'defensa interna en el exterior'".

Al definir el rol de EE. UU. en los conflictos de baja intensidad, establece que está dirigido a apoyar a “ (...) las fuerzas aliadas empeñadas en establecer, reanudar o mantener el control de ciertas áreas específicas amenazadas por la guerra de guerrillas, la revolución, la subversión u otras tácticas encaminadas a la toma del poder por una fuerza interna". Al hacer referencia a la "Defensa interna en el exterior", se refiere a la participación "(...) en cualquier programa de acción que haya tomado otro gobierno con el propósito de liberar y proteger al pueblo contra la subversión, el desorden y la insurrección" (Ejército de EE. UU., 1981).

El propósito que perseguía Estados Unidos en el entrenamiento y apoyo a los ejércitos nacionales, en nuestro caso al ejército guatemalteco, era que pudieran mantener el control de las áreas amenazadas por las fuerzas insurgentes.

Particularmente durante los inicios de la década de los ochenta, cuando Ronald Reagan asume su primer período presidencial, estuvo clara la intención de revertir los avances de las fuerzas revolucionarias en Centroamérica, lo cual patentemente está dicho en el "Documento de Santa Fe 1" que inspiró dicha política imperial.

La Facultad de Periodismo y Comunicación Social de la Universidad Nacional de La Plata tiene entre los materiales para clase de su cátedra virtual "Historia del Siglo XX, cátedra II" el 
Capítulo 5, "Proyectos políticos para América Latina”, Documento Santa Fe 1 (1980) y Documento Santa Fe 2 (1988). En su análisis del Documento de Santa Fe 1 afirma:

Cuando Ronald Reagan asumió la Presidencia de los Estados Unidos el 20 de enero de 1981, tenía claramente delineados los aspectos básicos de su futura política exterior y de su programa de gobierno. La administración de Reagan debía revertir rápidamente los efectos del llamado síndrome de Vietnam y las graves consecuencias del escándalo Watergate. Por otra parte, después de la lectura del Documento Santa Fe 1, preparado por el Comité de Santa Fe, era evidente que comenzaría una política agresiva de Roll-Back, es decir, la recuperación de espacios políticos, geográficos y estratégicos supuestamente perdidos por lo que los hombres de Santa Fe consideraban una conducta "débil" del antecesor de Reagan, el ex presidente demócrata, James Carter (Facultad de Periodismo y Comunicación Social / UNLP, 2013).

Claramente se anuncia la necesidad de recuperar los espacios políticos, geográficos y estratégicos que supuestamente se habían perdido ante el avance "del enemigo interno en el exterior", es decir, del comunismo.

$\mathrm{Al}$ exponer sus compromisos electorales en 1980, Reagan adelantó parte de lo que se proponía desde su versión fundamentalista de la política exterior republicana: “Durante mi gobierno, el comunismo no conquistará un solo centímetro más de tierra y me propongo recuperar territorios y pueblos caídos bajo su férula". Como se observa, la decisión imperial estaba férreamente tomada.

Para ser más específicos, la fuente referida cita algunos extractos del Documento de Santa Fe 1, entre ellos el siguiente: 
Las Américas se encuentran bajo ataque externo e interno. Una parte integral de la comunidad occidental, América Latina, está siendo invadida por satélites y sustitutos apoyados y abastecidos por la Unión Soviética (...) El Comité de Santa Fe insta a que los Estados Unidos tomen la iniciativa estratégica (...) y el estrechamiento de los vínculos con los países clave, así como mediante la ayuda a las naciones independientes para que sobrevivan a la subversión (Facultad de Periodismo y Comunicación Social / UNLP, 2013).

Como se ve, la distensión se ha terminado y la Guerra Fría adquiere en esos años toda su dimensión de agresión e intransigencia.

La decisión de Reagan, por lo tanto, fue revertir, a sangre y fuego, los avances revolucionarios en su zona de influencia, donde Centroamérica obviamente tiene particular importancia, "superando la debilidad" de la política exterior de Carter, manifestada en la presión ejercida hacia el respeto a los derechos humanos, la cual evidentemente estaba dirigida a enfrentar a la Unión Soviética, aunque tenía como "efectos colaterales" (los males no deseados pero producidos) las contradicciones con los regímenes dictatoriales, en nuestro caso, Guatemala.

La fobia anticomunista de Reagan, que era el sustento ideológico de la Guerra Fría, también se convirtió en la inspiración de la contrainsurgencia guatemalteca. El odio a los "delincuentes terroristas" era profundamente anticomunista. La consigna movilizadora en los entrenamientos y en los combates, particularmente de las tropas élites kaibiles era, precisamente, ese odio anticomunista.

Es así como en la región centroamericana, la política exterior de Estados Unidos tenía como objetivos derrocar al gobierno sandinista en Nicaragua, evitar el triunfo del FMLN en El Salvador y 
derrotar a la subversión guatemalteca, que se encontraba en proceso de agrupación como URNG.

Pero en esta lógica también es relevante señalar, como contrapartida a lo anterior, que en la estrategia de las fuerzas revolucionarias en la región las prioridades eran, en su orden, consolidar la revolución sandinista y abrirle camino inmediato al triunfo de la revolución salvadoreña. La revolución guatemalteca no estaba en esas prioridades regionales. Por esa razón, el apoyo logístico hacia la insurgencia guatemalteca era de importancia secundaria, lo cual limitó las capacidades de dichas organizaciones para responder ante la política contrainsurgente de tierra arrasada que impulsó el ejército guatemalteco, al amparo de las pretensiones que perseguía la política norteamericana.

En esta línea de razonamiento, de orden eminentemente político, definir como genocidio étnico la tragedia ocurrida en Guatemala es enmascarar un "genocidio" político, figura jurídica que, lamentablemente, no existe en la legislación internacional, ni nacional.

En este mismo sentido, el Tribunal Penal para la antigua Yugoslavia, caso Jelisic, (Sala de Primera Instancia), 14 de diciembre de 1999, párrafo 69, citado por Valencia Villa (2013), establece que el crimen de genocidio "no es aplicable a grupos políticos". Sin embargo, esta exclusión no resta importancia a la espantosa naturaleza de esta conducta delictiva. En tal sentido, Valencia Villa recuerda que “(...) en el Estatuto de la Corte Penal Internacional se incluyó como crimen de lesa humanidad, ‘la persecución a un grupo o colectividad con identidad fundada en motivos políticos' (art. 7h) lo que reconoce la existencia de la conducta que pretenda exterminar un grupo por razones políticas" (Valencia Villa, 2013). 


\section{Y si no es genocidio, ¿entonces habrá impunidad?}

La preocupación que produce la exclusión de los grupos políticos de la tipificación del delito de genocidio se hizo explícita en el III Foro Judicial Internacional "Nuevas propuestas para la prevención y sanción del delito de genocidio", celebrado en la ciudad de México el 19 y 20 de febrero de 2015. Entre las conclusiones de dicho foro, la número 4 sugiere “la revisión de la Convención para la Prevención y Sanción del Delito de Genocidio y del Estatuto de Roma con miras a su actualización y enmienda, para proteger a otros grupos humanos excluidos en la tipificación del genocidio, como los grupos políticos, sociales, culturales y económicos (...)" (Soto, 2015).

En contraposición con la anterior preocupación, para la autora Alicia Gil Gil (2014), no es necesario actualizar el delito de genocidio en el sentido de incluir a los grupos políticos como grupos protegidos por este tipo penal, en virtud de que estarían protegidos por el tipo penal de crímenes contra la humanidad.

Los crímenes de lesa humanidad, como parte de los delitos atroces, están referidos en el Estatuto de Núremberg, en la Convención sobre la imprescriptibilidad de los crímenes de guerra y los crímenes de lesa humanidad y en el Estatuto de Roma.

En el artículo 6 del Estatuto de Núremberg, se tipifican los Crímenes contra la Humanidad de la siguiente manera:

(...) el asesinato, la exterminación, esclavización, deportación y otros actos inhumanos cometidos contra población civil antes de la guerra o durante la misma; la persecución por motivos políticos, raciales o religiosos en ejecución de aquellos crímenes que sean competencia del Tribunal o en relación con los 
mismos, constituyan o no una vulneración de la legislación interna de país donde se perpetraron. Aquellos que lideren, organicen, inciten a la formulación de un plan común o conspiración para la ejecución de los delitos anteriormente mencionados, así como los cómplices que participen en dicha formulación o ejecución, serán responsables de todos los actos realizados por las personas que sea en ejecución de dicho plan (ONU, 1945).

Por su parte, el Estatuto de Roma, refiere este delito de la siguiente manera:

Artículo 7. Crímenes de lesa humanidad. 1. A los efectos del presente Estatuto, se entenderá por “crimen de lesa humanidad" cualquiera de los actos siguientes cuando se cometa como parte de un ataque generalizado o sistemático contra una población civil y con conocimiento de dicho ataque: a) Asesinato; b) Exterminio; c) Esclavitud; d) Deportación o traslado forzoso de población; e) Encarcelación u otra privación grave de la libertad física en violación de normas fundamentales de derecho internacional; f) Tortura; g) Violación, esclavitud sexual, prostitución forzada, embarazo forzado, esterilización forzada o cualquier otra forma de violencia sexual de gravedad comparable; h) Persecución de un grupo o colectividad con identidad propia fundada en motivos políticos, raciales, nacionales, étnicos, culturales, religiosos, de género definido en el párrafo $3, \mathrm{u}$ otros motivos universalmente reconocidos como inaceptables con arreglo al derecho internacional, en conexión con cualquier acto mencionado en el presente párrafo o con cualquier crimen de la competencia de la Corte; i) Desaparición forzada de personas; j) El crimen de apartheid; k) Otros actos inhumanos de carácter similar que causen intencionalmente grandes sufrimientos o atenten gravemente contra la integridad física o la salud mental o física.; 2. A los efectos del 
párrafo 1: a) Por “ataque contra una población civil” se entenderá una línea de conducta que implique la comisión múltiple de actos mencionados en el párrafo 1 contra una población civil, de conformidad con la política de un Estado o de una organización de cometer es ataque o para promover esa política; b) El "exterminio" comprenderá la imposición intencional de condiciones de vida, la privación del acceso a alimentos o medicinas, entre otras, encaminadas a causar la destrucción de parte de una población; c) Por "esclavitud" se entenderá el ejercicio de los atributos del derecho de propiedad sobre una persona, o de algunos de ellos, incluido el ejercicio de esos atributos en el tráfico de personas, en particular mujeres y niños; d) Por "deportación o traslado forzoso de población" se entenderá el desplazamiento de las personas afectadas, por expulsión u otros actos coactivos, de la zona en que estén legítimamente presentes, sin motivos autorizados por el derecho internacional; e) Por "tortura" se entenderá causar intencionalmente dolor o sufrimientos graves, ya sean físicos o mentales, a una persona que el acusado tenga bajo su custodia o control; sin embargo, no se entenderá por tortura el dolor o los sufrimientos que se deriven únicamente de sanciones lícitas o que sean consecuencia normal o fortuita de ellas; f) Por "embarazo forzado" se entenderá el confinamiento ilícito de una mujer a la que se ha dejado embarazada por la fuerza, con la intención de modificar la composición étnica de una población o de cometer otras violaciones graves del derecho internacional. En modo alguno se entenderá que esta definición afecta a las normas de derecho interno relativas al embarazo; g) Por "persecución" se entenderá la privación intencional y grave de derechos fundamentales en contravención del derecho internacional en razón de la identidad del grupo o de la colectividad; h) Por "el crimen de apartheid" se entenderán los 
actos inhumanos de carácter similar a los mencionados en el párrafo 1 cometidos en el contexto de un régimen institucionalizado de opresión y dominación sistemáticas de un grupo racial sobre uno o más grupos raciales y con la intención de mantener ese régimen; i) Por “desaparición forzada de personas" se entenderá la aprehensión, la detención o el secuestro de personas por un Estado o una organización política, o con su autorización, apoyo o aquiescencia, seguido de la negativa a informar sobre la privación de libertad o dar información sobre la suerte o el paradero de esas personas, con la intención de dejarlas fuera del amparo de la ley por un período prolongado. 3. A los efectos del presente Estatuto se entenderá que el término "género" se refiere a los dos sexos, masculino y femenino, en el contexto de la sociedad. El término "género" no tendrá más acepción que la que antecede" (ONU, 1998).

La intención de citar explícitamente la tipificación de los delitos de lesa humanidad es mostrar que, en términos jurídicos, aunque no se tipificara como genocidio lo acaecido en Guatemala durante el conflicto armado interno, existe este otro tipo de delito atroz que evitaría la impunidad para quienes perpetraron tan horrendas conductas.

\section{Los efectos sociopolíticos e históricos de considerar que en Guatemala hubo genocidio}

En los tribunales actualmente se está repitiendo el juicio por genocidio en contra de Efraín Ríos Montt y Mauricio Rodríguez Sánchez. Como se sabe, ya hubo una sentencia en primera instancia condenatoria para Ríos Montt y absolutoria para Rodríguez Sánchez, en mayo del 2013, la cual fue anulada por la Corte de Constitucionalidad. 
Este juicio tuvo el efecto de polarizar a la sociedad guatemalteca, agrupándose los sectores conservadores alrededor de la negación de la comisión de tal delito, mientras que los progresistas y de izquierda, particularmente las organizaciones de derechos humanos, todos con fuerte respaldo internacional, afirman que sí se perpetró.

Sin embargo, más allá de que sean los sectores conservadores y derechistas los que sostengan la ausencia de genocidio en Guatemala y que los progresistas afirmen lo contrario, la historia de Guatemala se ve tergiversada con esa vestimenta étnica con la cual se pretende ocultar un "genocidio" político. $\mathrm{Y}$ entre comillas genocidio, porque, como ya dije, tal delito no se puede tipificar cuando las intenciones que lo motivan son políticas.

Tratando de sintetizar las argumentaciones anteriores se puede afirmar que el anticomunismo promovido por Estados Unidos en el mundo fue el fundamento ideológico de la Guerra Fría y en esta orientación se formó y capacitó al ejército guatemalteco. La decisión de Ronald Reagan, especialmente explícita durante su primer período de gobierno (1981/1985) de hacer retroceder el avance de las fuerzas revolucionarias en el mundo, particularmente en Centroamérica, fue el marco de política exterior estadounidense que sirvió de contexto justificador y facilitador para el impulso de la estrategia de tierra arrasada que, en el marco de la contrainsurgencia, implementó el Ejército de Guatemala en ese período. Dicha decisión se expresa con mucha claridad en la Misión que define el Plan Operación Sofía, referida a exterminar a los elementos subversivos en el área. La intención del Ejército de Guatemala, en el contexto de la contrainsurgencia, fue aniquilar a los comunistas y sus bases de apoyo, fueran estas reales o supuestas por el ejército. 
Es más, a lo largo de la historia guatemalteca, nunca hubo la intención de eliminar a las poblaciones indígenas. Recordemos que, en la época colonial, el repartimiento y la encomienda fueron instituciones que, constituyendo dos caras de una misma moneda, se adecuaron hasta hacer compatibles los intereses de la Corona y de los conquistadores, ya convertidos en colonizadores. De igual manera, los llamados en la historia colonial "pueblos de indios" también respondieron a la satisfacción de dichos intereses, tener mano de obra cercana a las ciudades donde vivían los colonizadores, así como mayor funcionalidad para cobrar los tributos a la Corona.

La voracidad colonial no encontró en Guatemala metales preciosos para concretar el saqueo, en su lugar, la riqueza que se expolió fue la que se producía con esa combinación de tierra e indios.

Inveteradamente, la exclusión prevaleciente a lo largo de la historia nacional, que se expresa en el grosero racismo aún existente, no se ha manifestado en la intención de eliminar estos pueblos, sino que en cómo explotarlos hasta el límite posible. Ni las oligarquías, ni el Estado a su servicio, tuvieron tal pretensión exterminadora, sería incoherente con la pretensión de expoliarlos, convirtiéndolos en mano de obra para cultivar las tierras que les despojaban.

solo tergiversar la historia del país y de la lucha revolucionaria sino también eximir la responsabilidad del imperialismo estadounidense en el drama que debimos sufrir los guatemaltecos, nacido de la intervención de la CIA que derrocó al presidente Jacobo Árbenz Guzmán en 1954. Por eso, era comprensible observar al entonces embajador de Estados Unidos en Guatemala sentado en primera fila en las cortes aplaudiendo el juicio por genocidio.

Paradójicamente, a los guatemaltecos nos bastó que en 1999 el entonces presidente estadounidense William Clinton dijera, en relación al rol de su país en Guatemala, “es importante que yo 
exprese claramente que fue un error proporcionar apoyo para las fuerzas militares o unidades de inteligencia que se involucraron en represión violenta y generalizada (...)" para olvidar de inmediato la esencia anticomunista que inspiró las atrocidades ocurridas en nuestro país.

Para Estados Unidos la tergiversación de la historia nacional para invisibilizar su responsabilidad histórica en la tragedia que sufrimos los guatemaltecos le es plenamente conveniente. Saca del foco de análisis el tema del anticomunismo, como fundamento ideológico de la Guerra Fría, para explicar la barbarie cometida en Guatemala.

Si se acepta la tesis del genocidio étnico podría llegarse a la conclusión, como ya ha ocurrido en algunos artículos escritos por indígenas guatemaltecos de reconocido prestigio académico, que el Estado de Guatemala, por su naturaleza racista, utilizó el conflicto armado interno y la contrainsurgencia para hacer lo que su naturaleza le inspiraba, acabar con los pueblos indígenas. Y de manera complementaria en esta visión, la lucha revolucionaria impulsada por las organizaciones insurgentes solo habría cumplido la triste misión de construir el pretexto para que se concretara esa voluntad racista exterminadora. Esa es una tergiversación de la historia de la guerra.

No se puede negar el racismo aún prevaleciente en la sociedad y el Estado guatemalteco, el cual, sin duda, debió haber estado presente durante el conflicto armado por parte de los actores hegemónicos. Pero esta vergonzosa realidad no fue la que determinó la intención de la política institucional del Estado guatemalteco de impulsar la "tierra arrasada". Esta fue para aniquilar a los "subversivos" y sus bases sociales y políticas, sin importar que fueran hombres o mujeres, niños o ancianos, indígenas o mestizos. La magnitud de la respuesta correspondió a la percepción de 
riesgo que tenían los sectores hegemónicos. En los años sesenta fue el oriente del país, básicamente habitado por mestizos, el territorio donde se expresó la acción criminal del ejército guatemalteco, en los años ochenta el principal escenario de la guerra fue el occidente y el norte del país.

El odio anticomunista inyectado hasta la médula por la potencia hegemónica en los militares guatemaltecos por la formación que recibieron en el marco de la Guerra Fría, fue mens rea de su conducta criminal. Darle vestimenta étnica a esta tragedia nacional es tergiversar la naturaleza del conflicto armado guatemalteco. Efectivamente fue un "genocidio", pero uno inexistente en la tipificación penal de este delito, porque en su momento, y por razones de lucha de las potencias mundiales, se excluyó esta intención (política) en dicha tipificación penal.

\section{Pero no puede haber impunidad}

En todo caso, la tragedia sufrida por el pueblo guatemalteco, no solo por los indígenas, no debe quedar impune. Para ello existe la tipificación debida en los delitos de lesa humanidad, cuando se afecta a la población civil en un conflicto armado. Al respecto ya argumentamos en páginas anteriores.

Tal como lo expresa Valencia Villa,

En los conflictos armados no internacionales el artículo 13 del Protocolo II de 1977 consagra el principio general de la protección de la población civil, en otras palabras, el principio de inmunidad jurídica de la población, que implica la prohibición absoluta de utilizar ciertos métodos de combate tales como los ataques directos contra la población civil y los actos de terror (art. 13.2), hacer padecer hambre a la población civil (art. 14, protección de 
los bienes indispensables para la supervivencia de la población civil), y los desplazamientos forzosos (art. 17) (2013, p. 45).

Este principio general de protección de la población civil se encuentra consagrado en el artículo 13.1 del Protocolo II de 1977: “La población civil y las personas civiles gozarán de protección general contra los peligros procedentes de operaciones militares". Este concepto "(...) es negativo y privativo: designa a la población que no es actor del conflicto armado, que no empuña las armas y, además, que es objeto de la violencia de los actores del conflicto armado". (Valencia Villa, 2013).

La conducta criminal del ejército guatemalteco, del Estado contrainsurgente que entonces existía y las responsabilidades individuales correspondientes, porque el derecho penal siempre es personal, no se puede explicar, en lo fundamental, a partir del racismo. Concebirlo así es producto de una construcción jurídica que le da una vestimenta étnica al drama nacional que vivió el pueblo guatemalteco.

\section{El futuro de las luchas sociales}

En la discusión actual relativa al genocidio en Guatemala es pertinente recordar el debate sobre racismo y lucha de clases que se dio en los años setenta en nuestro país.

Hoy, asentar en la historia que se cometió genocidio étnico contra los pueblos indígenas en Guatemala fomenta de manera sustancial una lucha social que pierde sus anclajes clasistas y los sustituye por el anclaje étnico. Más allá de reconocer que, en la postmodernidad, las identidades alrededor de las cuales se pueden aglutinar las luchas sociales trascienden el anclaje clasista que privó en la edad moderna, no deberíamos obviar su esencialidad, 
como un fundamento básico de la pobreza, la desigualdad y la exclusión que aún persisten en el mundo (en muchos casos profundizado).

De igual manera, el nuevo mapa geopolítico mundial, con todo y su multipolaridad, no implica desconocer los intereses que las potencias contemporáneas tienen en él, los cuales, dadas sus pretensiones imperiales, nunca podrán dejar de ser estratégicamente perversos para los países subalternos.

Aunque resulte aún atrevido afirmarlo, contemporáneamente se empieza a mostrar que las luchas sociales por el reconocimiento de diversidad de identidades, por justas y movilizadoras que sean, pueden terminar diluyendo la esencialidad de las injusticias, en los países y en el mundo, que son básicamente de orden socioeconómico.

Aceptar que la tragedia guatemalteca fue un genocidio étnico implica que la lucha antioligárquica y antiimperialista quede históricamente invisibilizada o, si acaso, circunscrita a categorías secundarias. La polarización tendería entonces a ser étnica y su superación pasaría por reivindicaciones distantes de los intereses colectivos de naturaleza clasista o antiimperialista. Pero, además, dota al futuro del país de un elemento subjetivo, de orden racial, que ya se ha visto en la historia y en la contemporaneidad mundial, que puede llegar a tener una potencialidad altamente controversial. Esta advertencia no implica negar la necesidad de continuar la lucha contra la discriminación y por el efectivo reconocimiento de la identidad y los derechos de los pueblos indígenas, que le deberían ser propios a ese reconocimiento.

Pero en un contexto donde se defina la existencia de un genocidio étnico, la connotación, formas y consecuencias de la lucha porque se cumpla el Acuerdo sobre Identidad y Derechos de los 
Pueblos Indígenas tendría otra naturaleza, distante del espíritu y contenido integral de los Acuerdos de Paz y de la heroica lucha revolucionaria que los permitió.

Es cierto que no hay manera de avanzar hacia la conciliación nacional dándole vuelta a la página del conflicto armado interno sin haberla leído adecuadamente. Y también es cierto que esa lectura supone que no prevalezca la impunidad y que se concrete la justicia transicional. Esa necesidad puede polarizarnos y eso es lamentable. Pero no se puede obviar, especialmente en lo referido a los crímenes atroces.

Ahora bien, insistimos, lo que no se puede aceptar es que reivindicando este derecho a la justicia se tergiverse la historia y se exacerbe con argumentos inapropiados una lucha social producto de esa tergiversación. La pobreza generalizada, la exclusión y la desigualdad son razones estructurales que deben superarse y, para lograrlo, hay que saber reconocer a las fuerzas hegemónicas, nacionales e internacionales, que mantienen el statu quo estructural e identificar las amplias alianzas que hay que construir para enfrentarlas.

El racismo ciertamente permea todo el tejido social guatemalteco y está presente en el actuar del Estado; pero esta realidad, cuya transformación es necesaria, no debe encubrir los cimientos estructurales, nacionales e internacionales, que deben derrumbarse para avanzar hacia el desarrollo nacional y la paz social.

\section{Bibliografía}

Comisión para el Esclarecimiento Histórico (1999). Guatemala, memoria del silencio. Guatemala: F\&G Editores.

Código Penal [Código] (2009); (1973).Decreto 17-73.3ra. ed. Guatemala: LaLey.Disponibleen:<http://ww2.oj.gob.gt/es/QueEsOJ/EstructuraOJ/ 
UnidadesAdministrativas/CentroAnalisisDocumentacionJudicial/ cds/CDs\%20compilaciones/Compilacion\%20Leyes\%20Penales/ expedientes/01_CodigoPenal.pdf>

Ejército de EE.UU. (1981). Manual FM 100-20. Estados Unidos: Cuartel General de la Secretaría del Ejército de EE.UU. Obtenido de https://nsarchive2.gwu. edu/NSAEBB/NSAEBB297/index2.htm

Ejército de Guatemala. (1982). Operación Sofía. Obtenido de https:// nsarchive2.gwu.edu/NSAEBB/ NSAEBB297/index2.htm

Universidad Nacional de La Plata, Facultad de Periodismo y Comunicación Social (2013). Historia del Siglo XX, cátedra II, Capítulo 5, "Proyectos políticos para América Latina" Documentos Santa Fe 1 (1980) y Santa Fe 2 (1988). Disponible en: <http://perio.unlp.edu.ar/catedras/sigloxxcatedra2>

Gil Gil, A. (2014). Genocidio y justicia penal internacional. Trabajo presentado en la Conferencia en la Universidad Sergio Arboleda, Santa Marta, Colombia. Disponible en: <https://www.youtube. com/watch?v=BBOd2YqugS8>

Organización de las Naciones Unidas (2014). Marco de análisis para crímenes atroces, una herramienta para la prevención. Nueva York: Oficina de las Naciones Unidas sobre la Prevención del Genocidio y la Responsabilidad de Proteger.

Organización de las Naciones Unidas (1998) Estatuto de Roma de la Corte Penal Internacional. Disponible en:

$<$ https://www.oas.org/36ag/espanol/doc_referencia/estatuto_ roma.pdf>

Organización de las Naciones Unidas (1968) Convención sobre la imprescriptibilidad de los crímenes de guerra y de los crímenes de lesa humanidad. Disponible en: <http://www.ohchr.org/SP/ ProfessionalInterest/Pages/WarCrimes.aspx $>$ 
Organización de las Naciones Unidas (1949) Los Convenios de Ginebra de 1949. Disponible en: <https://www.icrc.org/spa/assets/files/publications/convenios-gva-esp-2012.pdf>

Organización de las Naciones Unidas (1948) Convención para la prevención y la sanción del delito de genocidio. Disponible en:

$<$ http://www.oacnudh.org.gt/estandares/docs/Instrumentos/ Crimenes/Convenlesa2.pdf>

Organización de las Naciones Unidas (1946a) Resolución 96(I) El crimen de genocidio. Disponible en: <http://www.un.org/es/comun/ docs/?symbol=A/RES/96(I)>

Organización de las Naciones Unidas (1945) Estatuto del tribunal militar internacional de Núremberg. Disponible en:

<http://www.oacnudh.org.gt/estandares/docs/Instrumentos/ Humanitario/Nuremberg1.pdf>

Soto Santiago, W. (2015). Conclusiones del III Foro Judicial Internacional “Nuevas propuestas para la prevención y sanción del delito de genocidio". México.

Disponible en:

$<$ http://embajadamundialdeactivistasporlapaz.com/forosjudicialesinternacionales/es/conclusiones-tercer-foro-judicial-internacional-nuevas-propuestas-para-la-prevencion-y-sancion-del-delito- de-genocidio/>

Unidad Revolucionaria Nacional Guatemalteca (1985). Balance de la situación del ejército enemigo. Guatemala: Mimeo.

Valencia Villa, A. (2013, marzo) “El genocidio y los deberes de humanidad en el Código Penal guatemalteco", Revista Opus Magna Constitucional, 7. 



\section{Revoluciones en el Caribe: La memoria y los peligros del silencio*}

\section{Félix Valdés García}

El primero de enero de 1804, Haití se declaraba un Estado independiente, una República negra, resultado de una revolución de trece años de contingencia. Siglo y medio después, también un primero de enero, triunfaba en Cuba una revolución como consecuencia de una asonada radical que resumía casi un siglo de rebeldías contra el poder colonial y la esclavitud - primeramente - , y contra las injusticias, las discriminaciones, la dependencia y las desigualdades en esta isla, después.

Granada, una pequeña porción insular del Caribe, el 13 de marzo de 1979, con Maurice Bishop a la cabeza - un líder más grande

\footnotetext{
* A propósito de la III Escuela Internacional de Postgrado "Paradigmas críticos de la emancipación", dedicada al tema "Revolución y memoria", algunos apuntes sobre la trascendencia de los procesos revolucionarios en el Caribe, sus rasgos distintivos, los silencios de sus historia y los peligros en la recuperación de sus memorias.
} 
que su ínsula -, iniciaba un proceso revolucionario que prometía emancipación para los esclavos de antaño, luego negros olvidados y dejados al buen parecer por la corona británica. La emancipación femenina, la autogestión popular, la educación, el turismo para negros y hasta la producción de jaleas fue estímulo y fuerza movilizadora.

Sin lugar a dudas, vivimos en una región de revoluciones, de cambios radicales, dados no solo en el momento triunfal del evento sino en el proceso que le sigue; y todos ellos acaecidos por medio de la violencia revolucionaria, la toma del poder político y los más disímiles intentos por lograr subvertir el orden precedente. ${ }^{1}$

La revolución ha constituido uno de los temas principales del pensamiento crítico caribeño que pretende, desde este espacio, recuperar las fuentes, las lecturas realizadas y visibilizar la trascendencia de los actos, una vez que la tórrida región es testigo de paradigmáticos procesos de su tipo. En estas islas las llamas han llegado al cielo para convertirse en sucesos, en texto esencial del mundo colonial, del Sur; procesos que después de acaecidos han forzado a Occidente a ser diferente y provocar un "giro del revés".

1 Además de estas revoluciones, en la región vecina se han dado procesos de cambio radical, en países como México en 1910, Nicaragua el 19 de julio de 1979, cuando los Sandinistas en la vecina Centroamérica destronaban a Somoza y en gustoso festín el comandante Humberto Ortega se acostaba en la cama del dictador como muestra de la victoria. Hoy Venezuela, otro país vecino ha dibujado en el mapa político de las alternativas la salida del sistema y el inicio de un proyecto que, contra todo pronóstico, se ha hecho obsesión de los presidentes de Estados Unidos y Colombia, mucho más que sus innumerables dificultades domésticas. Sus logros han sido ocultados, sacados de la luminosidad que ellos mismos pudieran proyectar en este hemisferio. 
Si tomamos a la revolución haitiana y a la cubana - arquetipos de su tipo en todos los órdenes-, constatamos que ambas hicieron cambiar no solo las relaciones metrópolis colonia y neocolonia, las relaciones geopolíticas, económicas, jurídicas, sino significaron cambios en algo más duradero, en los órdenes ontológicos, epistémicos, de las lógicas de la dominación, en lo simbólico, lo axiológico, lo estético, hasta desquiciar los modos de ver y comportarse asumidos antes como tradicionales. Tras ellas - una en la década final del siglo XVIII, la otra a mediados del siglo XX-, cambió la cosmovisión, aquello que los filósofos soviéticos en mis años de formación hubiesen dicho "el cuadro científico del mundo", o Michel Foucault, los alemanes y franceses la Lebenswelt, la episteme tradicional. Pero, sin dudas, poco se apunta cotidianamente en nuestras cátedras al respecto.

Gracias al dominio colonial, Europa y Occidente se autoconstituyeron como tales. Europa dejó de ser un espacio arrinconado por el Islam (Dussel, 1994) para hacerse 'centro', tener todas las "verdades absolutas, los ideales de belleza" - como dijera Frantz Fanon (1968), pues era "como si Occidente tuviese las llaves de la bóveda y de allí llegasen las ideas, el arte, la filosofía, las ciencias, también las instituciones, y todo aquello que nos salvará a todos". El 'centro' generó una 'periferia' más allá del mar de los sargazos - de esa "línea abismal" como dice Boaventura de Sousa Santos (2009, p. 12) - , y fueron ellos depositarios, dueños, administradores de toda la verdad. Desde sus alturas, miraron como la "Hibris del punto cero", al resto del mundo, como dice Santiago Castro Gómez. De su práctica particular crearon “lo universal”, se situaron en la escala superior del desarrollo, fueron el progreso, el índice mismo de la civilización, el modelo y el canon.

Pero su representación del mundo impide ver al mundo tal cual es. Ello les impidió ver lo que sucedía en Haití; les impidió 
mirar hacia abajo o más allá del océano, navegando al poniente. Entonces ahí es donde más 'cojeó' el saber occidental. Y ahí es donde falló. No tuvieron capacidad para concebir una revolución de esclavos con la máxima consigna de eliminar la esclavitud, ni la revolución de la Sierra Maestra que eliminaría del modo más radical y definitivo los privilegios de terratenientes, acabaría con los latifundios, los casatenientes, los propietarios extranjeros de grandes fábricas y centrales azucareros. Y es que las verdades de su onto, de su episteme han sido más difíciles de demoler que sus ideologías o sus políticas del momento.

¿Por qué estas dos revoluciones del Caribe han forzado a Occidente a reconceptualizar, a remover lo que se daba como sabido? ¿Por qué aseverar que se han dado cambios no solo en los órdenes políticos y económicos, geopolíticos, sino en órdenes de mayor trascendencia como en lo ontológico, gnoseológico, las epistemes, los valores, la estética? ¿Y por qué cuesta tanto esfuerzo hacerlo notar? En ello me detengo, teniendo como referente a dos revoluciones por antonomasia: la haitiana $\mathrm{y}$ la cubana, y una lectura que guía a otras: la de Michel RolphTrouillot, intelectual haitiano que contagia con sus análisis sobre los silenciamientos de la historia y de la revolución en su isla y nos traslada a pensar en el valor de la memoria y las justas maneras de hacerlo. Compartimos con él y con otros autores que han puesto su mirada en la trascendencia de estos hechos en la región, como C.L.R. James, A. Césaire, G. Lamming, E. Williams, Juan Bosch, para ver aquello que se repite y se expande.

Las revoluciones del archipiélago Caribe han hecho girar la noción del sujeto de la historia, han permitido involucrar y hacer recuperar la "esencia" enajenada, la dignidad humana sojuzgada. Con ellas el sujeto del cambio se desplazó del norte al sur, a África, al Cono Sur americano, al Caribe, a Asia, como apuntara 
en 1961 Jean Paul Sartre al prologar Los condenados de la tierra de Frantz Fanon. “Europa hace agua por todas partes. ¿Qué ha sucedido? Simplemente, que éramos los sujetos de la historia y que ahora somos sus objetos" (Fanon, 1965) - sentenció Sartre, sorprendido por los manuscritos que el inquieto martiniqueño, sentenciado de muerte, le había puesto en sus manos en Roma, un día de agosto de 1961 cuando vino expresamente desde Túnez para ese encuentro.

Con las revoluciones en el Sur surge un sujeto nuevo, involucrado en el cambio, que como, afirmara Fanon, es con ella y por medio de ella que se emancipa y se hace un hombre y mujer nuevos, que recupera su humanidad, su universalidad y salva a Occidente de la crisis moral, esa que en 1948 le soltara en cara Aimé Césaire a todos los presentes en ceremonia oficial de la Asamblea Nacional Francesa cuando jubilosamente celebraba el centenario del fin de la esclavitud en las colonias francesas. ${ }^{2}$

El involucrarse en la revolución hace que la mujer se quite el velo, que el intelectual radicalice su compromiso, que los partidos políticos del desorden total que significa la descolonización dejen de ser los habituales partidos de la tradicional política de occidente. La revolución, que es el acto mismo "afecta al ser", lo modifica, "transforma a los espectadores aplastados por la falta de esencia en actores privilegiados, recogidos de manera casi grandiosa por la hoz de la historia. Introduce en el ser un ritmo propio, aportado por los nuevos hombres, un nuevo lenguaje, una nueva humanidad". De tal modo que tanto Fanon como el Che concluyeron que estos procesos emancipadores crean a mujeres

2 Este discurso de Césaire dio lugar dos años después a la publicación de esencial texto Discurso sobre el colonialismo. 
y hombres nuevos, crean sujetos del cambio, más allá del cinismo y la apatía, la desconfianza acomodada e instalada hoy en el Norte.

La revolución - en Haití y en Cuba-, involucró al esclavo, al excluido, envolvió y emancipó a las mujeres y hombres, los puso a vivir en otra dimensión, aquella que justamente les emancipaba. Les envolvió como torbellino, como huracán, les puso a girar sin saber siempre la exactitud meridiana del a dónde vamos, pero les movilizó. Ya a finales del siglo XIX José Martí, comprometido con un proceso que resignificaba todas las concepciones sobre la verdad, el bien y el mal, lo justo y lo injusto, lo bello y lo feo, destacó que era precisamente la revolución la madre de una nueva visión que se imponía, de una nueva perspectiva del mundo. La revolución fue “la madre, la santa, ella fue la que arrebató el látigo al amo, ella fue la que echó a vivir al negro de Cuba, ella fue la que levantó al negro de su ignominia y lo abrazó, ella, la revolución cubana" (Martí, 1975).

\section{Revoluciones impensables}

Como asume Trouillot, la revolución haitiana, y ello extensible como rasgo al resto de las grandes revoluciones en las Antillas, han sido sucesos impensables e impensados: las dos acciones a la vez.

Cuando a Europa comenzaron a llegar las noticias de las sublevaciones haitianas, estas no se aceptaban, había incredulidad y las noticias se consideraban falsas. Ni los plantadores mulatos del ala izquierda de la Asamblea Francesa concebían la sublevación masiva como posibilidad. Para el propio mulato Jean Pierre Brissot, "Amigo de los Negro"', fue increíble aceptar una movilización de más de cincuenta mil esclavos, organizada de modo 
vertiginoso, con todos unidos, frente a los plantadores en la isla. Tampoco se admitía que pudiera ser un plan de los negros esclavos mal vestidos y mal alimentado porque, de serlo, las tropas francesas los hubiesen derrotado ya. ¿Quién desde fuera sería el agitador de tal evento? ¿Vendrían los ingleses en su ayuda? ¿Quién sería el culpable? Se argüía sin dar suficiente crédito a la novedad. De un modo semejante sucedió en Cuba. Los más acaudalados dejaban a la servidumbre en las casas para que cuando regresaran todo estuviera a buen resguardo, o en diabólica campaña enviaron a sus hijos, algunos de meses, a los Estados Unidos para ponerlos a salvo de un fenómeno transitorio.

Ambos procesos han sido impensables, no por inauditos sino porque no caben en los esquemas de pensamiento dominantes, en esas cómodas referencias codificadas, en las epistemes del mundo establecido. Según el sociólogo francés Pierre Bourdieu, citado por Trouillot, impensable es aquello para lo que no tenemos instrumentos adecuados de conceptualización. Y ese es el caso. No existen referentes. Estamos convencidos de su inoperatividad, de su imposibilidad. Tanto la revolución haitiana como la cubana iniciada en 1868, como en su última fase victoriosa de 1959, fueron revoluciones impensables porque deshacían el marco de referencias, las verdades, lo considerado como lo real, el ser, aquellos pilares sobre los cuales se sostenía el sistema colonial y neocolonial. Entre las nociones infalibles estaban: la legitimidad de la esclavitud, la idea de las razas humanas, la imposibilidad de la independencia en las Américas (mucho menos probable aún, la creación de un Estado negro, revolucionario, capaz de sostenerse), la expropiación y nacionalización de las grandes propiedades extranjeras, en su mayoría norteamericanas, confiscadas y sujetas a indemnización. 
Durante el período colonial, para las representaciones dominantes francesas y españolas, los negros esclavos eran seres apacibles, serían obedientes y serviles, la libertad constituía una quimera inalcanzable para ellos y, de haber una sublevación, esta jamás sería total, mucho menos triunfante. Las sublevaciones de las que se daba cuenta eran consideradas fenómenos aislados, locales, fácilmente controlables con los tradicionales métodos violentos, fascistas, tantas veces comprobados por el poder colonial, a los cuales hace referencia de modo tan ilustrativo James cuando dice que "el látigo era tan corriente como el viento y se recibía con más certidumbre que el alimento" y describe, para asombro de sus lectores, el sadismo de los métodos empleados por los esclavistas, pues "a los esclavos se les ponía hierro en las manos y los pies, bloques de madera que debían arrastrar; máscaras de latón para evitar que comieran caña de azúcar, collares de hierro, azote, sal, pimienta, limón, carboncillo, acíbar y cenizas calientes en las heridas sangrantes; cera ardiente, azúcar de caña hirviente en sus cabezas; quemas, enterramientos hasta el cuello, mientras las mutilaciones de extremidades, orejas y partes pudendas que les privara de placeres, era cosa cotidiana hecha por el amo, así como las violaciones y la muerte". Pero todo fue así asevera James - , hasta una noche tormentosa", aquella del 14 de agosto de 1791 en Bois Caiman, cerca de Le Cap.

No obstante, a los actos "aislados" de sublevación se les vaciaba de contenido político, y se justificaban por la incapacidad de adaptación del esclavo, por una enfermedad, su carácter dislocado, los excesos del amo tal con el esclavo revelado o la simple razón individual pasional, como la del esclavo Francisco en la novela del escritor cubano Anselmo Suárez y Romero, ante la cual se revelaran los jóvenes creadores del ICAIC para recrear una historia más creíble que la entregada al delegado antiesclavista inglés 
Richard Madden en 1838. Sin dudas debió haber otro Francisco, rebelde, temerario, decidido a la revuelta, a la sublevación. Para la representación colonial la patología estaba del lado del negro.

Del mismo modo, a finales de los años cincuenta, en plena guerra fría y posthisteria macartista en los Estados Unidos, el comunismo podría ser peligro en el Senado, pero jamás podría urdirse en la isla al sur de su frontera. Y, aún peor, ya con la revolución en curso, la burguesía cubana no aceptaba la verdad de la revolución. Lo que incluso estaba sucediendo, entre 1793 y 1804 en Haití, o en 1959 en Cuba, no era una verdad posible. No encajaba, no se acomodaba con lo establecido. Tanto en los panfletos como en las publicaciones oficiales francesas en las postrimerías del siglo XVIII, como de finales de los cincuenta del siglo XX en Cuba y Estados Unidos, daban muestra de la incapacidad de los franceses o, en este caso, del gobierno de Batista o de Estados Unidos para comprender, acorde a su visión, que la revolución era una realidad, era una verdad que se desplegaba. Estando en marcha eran aún impensables, porque los sistemas de creencias tienden a la estabilidad y reconocer o dar crédito a las revoluciones significa reconocer las fallas, las vulnerabilidades de los sistemas.

Durante los trece años de la revolución en la próspera colonia de Saint Domingue las noticias en Europa fueron distorsionadas. La constitución de un Estado independiente era imposible, impensable, aun después de enero de 1804. Entonces vino el rechazo, la no aceptación y el castigo. Haití sufrió una condena durante el siglo XIX y Cuba la vive aún hoy, argumentado todo por una misma lógica, expresado en el fortalecimiento del bloqueo de sesenta años de existencia con las actuales sanciones contenidas en el capítulo 3 de la Ley Helms Burton. Fue más fácil aceptar la 
derrota de Napoleón en Rusia que la creación de Haití, la derrota en Vietnam que en Bahía de Cochinos.

Todo se debe a la incapacidad de los esquemas mentales inamovibles para aceptar lo nuevo. El problema está en el fundamento, en los presupuestos básicos en los cuales se sostiene el saber, la episteme que soporta otros saberes, lo cual significa un dato más profundo que las moldeables ideologías. Estas pueden moverse, readecuarse, las primeras no. Los nuevos datos de la realidad, el cambio radical, no se ajusta a los marcos referenciales y a la representación de la ontología occidental. Es una imposibilidad histórica. No hay marco conceptual de referencia que permita entender la radicalidad antiesclavista, antirracista negra, anticolonial del proceso que se desenvolvía en la colonia francesa, o en Cuba, tras 1959. Doce años después del triunfo, Fidel decía, refiriendo a la incapacidad de los "conocedores" de Cuba para definirnos y estudiarnos: “Todavía, con toda precisión, no tenemos siquiera un nombre, estamos prácticamente sin bautizar".

Estas dos revoluciones han, sido sobre todas las cosas, revoluciones en las nociones ontológicas, en las epistemes, en los valores, en la nueva estética y para las lógicas de Occidente. Y he ahí su trascendencia, muy a pesar de los intentos sistemáticos por silenciarles, subvalorarles o trivializarles. Con ellas en el mundo colonial se desmorona la invulnerabilidad del sistema colonial, esclavista, la avalada inferioridad del africano esclavizado. La libertad del esclavo completó la idea burguesa de la libertad y la igualdad e hizo temblar el ideal de la fraternidad. La esclavitud tocó su fin y fue demanda consciente de los líderes haitianos. Los esclavos negros mostraron capacidad para desafiar el poder, usurparlo, decidir y encabezar un proyecto alternativo, con todos los vaivenes, modos y contrariedades que tuviera. 
El esclavo tomó autoconciencia de sí y se reveló contra el amo, una figura que tomó Hegel (1807) a medias para referir el fenómeno de la autoconciencia en su Fenomenología del espíritu. El filósofo se aprovechaba de la imagen tantas veces referida en la prensa y en la revista Minerva sobre la sublevación iniciada en la llanura norte de Saint Domingue y la creación de un nuevo Estado-nación, con una constitución mucho más radicalizada en 1805 que las versiones precedentes. Allí, en el artículo 14 se afirmaba: "Todas las distinciones de color necesariamente desaparecerán entre los hijos de una y la misma familia (...); los haitianos, de aquí en adelante, serán conocidos por la denominación genérica de negros".

La realidad no está siempre hic et nunc ('aquí y ahora'), los pueblos diferenciados en abstracto por una supuesta línea de color no tienen una jerarquía fija, no son unos superiores a los otros, unos civilizados y otros salvajes, unos con historia y otros sin ella. Los negros no serán más inferiorizados muy a pesar de los esfuerzos del racismo científico de las sociedades antropológicas y médicas europeas del siglo XIX. Toussaint animó la construcción de hoteles en Le Cap, impulsó la construcción de edificios nuevos en la ciudad devastada, construyó carreteras para unir a puntos distantes de Haití y se preocupó por recuperar la agricultura en las haciendas quemadas. Antenor Firmin con orgullo alegaba ante los racistas seguidores de Gobineau en París, ochenta años después, sobre la capacidad de los haitianos en todas las esferas de la vida social, las artes, las ciencias, las humanidades. Y aunque su libro es sobre la insostenible afirmación de la desigualdad del negro, dedica páginas a elogiar la sabiduría, la capacidad, las riquezas intelectuales de Haití para 1885.

La razón y la ciencia europea, las disciplinas diferenciadas entonces evidencian su incapacidad para explicarlo todo. Se hicieron 
inútiles para aprehender la realidad de esta parte del mundo. No obstante, la religión y "la magia" mostraban haber jugado un papel movilizador y de éxtasis, insuflador de coraje, de estímulo para la emancipación total.

Desde entonces las mercancías no vendrán ya más de las Antillas a Francia como lo era antes; la trata y la esclavitud no serán ya más estados eternos ni negocios confiables. Adam Smith lo advertía, pero no por humanitarista sino por el cierre de un tipo de economía y la necesidad de otra, basada en el liberalismo.

Se hizo otro el mundo a la sazón. Llegó el fin, no de la Ilustración con el fin de la esclavitud sino el final del falso universalismo, abstracto, construido por el mundo occidental moderno. Fue el fin de un tiempo y el inicio de otro, generado por una revolución sucedida, no en Francia o los Estados Unidos, sino en una colonia, liderada por esclavos negros que se sublevaron contra el poder colonial y la esclavitud. La libertad fue la primera ganancia, seguida de la independencia. Lo primero, ni los franceses, ni los norteamericanos, fueron capaces de concebirlo en Norteamérica en 1777 o en Francia en 1789. ¿Será que fue posible hacer esta lectura, conscientemente?

A las islas más cercanas llegó el “horror” de Haití. Cundió el pánico entre los hacendados y el poder colonial español en Cuba. Se construyó el mito del desastre haitiano y se apelaba a la incapacidad de los negros para manejarse a sí mismos. Se hizo ver aquello como un proyecto negativo, moralmente lo malo, estéticamente feo. A la revolución iniciada en Cuba en 1868 se le antepusieron, caricaturizadamente dos caminos: o ser Haití, que es ser como el África salvaje, o ser española y, entonces, civilizada. No obstante, a poco más de medio siglo de la haitiana, la revolución que se inició en Cuba de 1868 a 1898 fue integradora, antirracista, anticolonial y abogaba por una república donde la 
primera ley fuera el culto a la dignidad plena de los hombres y mujeres cubanas, sin importar el color de la piel.

Asombra que tales convicciones cubanas de finales del siglo XIX eran enarboladas en tiempos de auge del racismo científico en Europa, cuando ocurrían linchamientos y guerra civil en el sur de los Estados Unidos. Pero como dijera Martí (1975) todo esto comenzó a suceder en una isla en la cual "el látigo, lo mismo que el sol, se levantaba todos los días", para que los hombres y mujeres como bestias fueran arreados y castigados; "puestos a engendrar, despedazados por los perros en los caminos". Esa gran pena del mundo era vivida por el hombre negro en Cuba, antes y durante la revolución del sesenta y ocho, hasta que se alzaron en guerra, rompieron desde su primer día de libertad los grillos de sus siervos, y convirtieron a costa de su vida la indignidad española en un pueblo de hombres libres. Fue ese acto, fue la revolución la que invirtió el orden, la que hizo girar la verdad.

Pero, unos años después, llegó de nuevo la soez ignominia, los rezagos, los esquemas ajenos porque como advirtiera Martí (1975), "la institución de la esclavitud" es muy difícil de "desarraigar de las costumbres y de la ley (...) lo que se borra de la constitución escrita, queda por algún tiempo en las relaciones sociales". Y así fue en los años que siguieron, sobre todo con la imposición que venció, del american way of life, que tuvo hitos vergonzosos como la muerte de Quintín Banderas, la Guerra del 12 y tantos otros actos inmemorables.

¿Cómo concebir, desde los esquemas del Norte, desde las representaciones occidentales, desde la ontología, la epistemología, la axiología, la estética occidental, estos nuevos datos? La negación de la revolución, el castigo a la revolución, el silenciamiento sistemático ha sido la disposición. 


\section{Revoluciones impensadas}

Otro de los rasgos de las revoluciones insulares, la haitiana, la cubana o la granadina es que han sido procesos impensados. No estuvieron antecedidas suficientemente por un recio plan, un diseño exacto, un trazado preciso. Ellas adelantaron la realidad a la idea. El acto antecedió al concepto, el impulso muscular al razonamiento consciente. No ha habido plan exacto del acaecimiento. Los proyectos se desquician frente a la acción que es la que define el plan. Los ideólogos de la revolución francesa bosquejaron el cambio. Solo faltaba un líder que resultó ser Robespierre. En Haití no fue el "espartaco negro", del cual advertían Raynal y Diderot al poder francés del peligro en las colonias de ultramar.

En las islas, las revoluciones han generado al líder. Los dos, la revolución y el líder llegaron juntos. Tampoco fueron procesos que se acompañaron de intelectuales o teóricos con capacidad para urdir planes o advertir atajos. Más bien escaso fue su oficio. En el caso de Haití, la mayoría de los esclavos eran analfabetos. La palabra escrita no era medio de comunicación. Y las reivindicaciones eran tan radicales que solo los hechos dieron fe de ellas.

Los sucesos mismos, en su desenvolvimiento, han puesto, han planteado y han generado las demandas, ubicándose en el límite mismo de lo concebible, incluso para los líderes, quienes tampoco preconcibieron el curso radical que las transformaciones adoptarían. Con ello se desecha la capacidad magnánima y sobrenatural. El proceso define.

Ha sido rasgo de Haití y Cuba que el discurso quedó detrás del acto o al unísono con él. La práctica política ha desafiado cualquier idea, cualquier filosofía. De hecho, ambas revoluciones han 
producido escasos textos que anticipen o acompañen. Las revoluciones en el Caribe, al menos estas dos paradigmáticas, con ciento cincuenta y cinco años de diferencia la una de la otra a medir por la fecha de victorias, no tuvieron más preparación ideológica que la impuesta por los excesos de la realidad de dominación, pese a que la cubana tuvo la ventaja del tiempo, de los desarrollos tecnológicos y de la madurez de los años.

\section{El peligro del silencio}

La propia incapacidad para aceptar la trascendencia de las revoluciones insulares, más los intereses que detrás de ellas se mueven, ligado al dominio de la perspectiva occidental, de la tradición y las dinámicas académicas, han provocado el peligro del silenciamiento. Los dueños de la fórmula, los poseedores de las metodologías, de la ciencia, de las disciplinas y los manejadores de las ideologías, han sabido velarlos sucesos.

Como señala Trouillot, en el discurso de la dominación ha habido dos tropos de su retórica que han pretendido garantizar el silencio. Lo primero: Borrar el hecho. Los divulgadores, los autores de los libros de texto, hacen repetir que "eso realmente no sucedió", "no fue tan grave ni tan importante". "La esclavitud también afectó a los no negros", o ideas tales como “Cuba lucía índices de desarrollo superiores a los actuales".

En segundo lugar, persiste la intensión de vaciar de contenido exacto, de trivializar y de banalizar el suceso. Y aquí están prestos los especialistas que pueden afirmar que "los esclavos estaban mejor alimentados que los obreros ingleses", "los castigos no fueron tan severos" o "la educación de antes del cincuenta y nueve era superior a la de hoy”, “La Habana era lujosa y todo era prodigalidad". 
Al final de los intentos sistematizados, hay una intencionalidad final: las revoluciones en nuestro mundo pasan de impensables, impensadas, silenciadas a convertirse en un no acontecimiento.

La revolución haitiana no ha existido. No entró en los textos escolares, en los libros de historia, en la enseñanza, ni en Haití ni en Cuba, ni en América Latina o en las escuelas francesas. El proceso violento pasó de ser revolución a constituir una revuelta, una rebelión. Es tan increíble el silenciamiento, el desconocimiento premeditado, que los ingleses perdieron a más de sesenta mil soldados, pero ellos no están, no se reconocen; y Francia perdió a más franceses en Santo Domingo que en Waterloo, sin embargo, poco se registra. Los diccionarios de historia no tienen entradas a la revolución haitiana. Eric Hobsbawn en su libro La era de las revoluciones apenas hace menciones a Haití, como apunta Trouillot. Y en las escuelas del sur de la Florida, se enseña con sentido invertido la participación de Cuba en África durante el proceso de descolonización, lo mismo que el hecho de Playa Girón o Bahía de Cochinos.

Pero la pretensión de vaciar de contenido, de trivializar y de banalizar puede lograrse aun cuando con los mejores empeños se entroniza en los sistemas de educación y se construyen narrativas que se repiten como mantras o letanías. Basta con visitar un museo cubano hoy, no importa si en La Habana, Girón o Santiago de Cuba. La narrativa repetitiva, descontextualizada, facilista se tira en cara. Eso sí, una narrativa con coherencia, aunque pálida, simplificadora, llena de lugares comunes, como salidas de un mismo molde. Si se trivializa, se vacía de contenido, se ponen muchas cosas en el silencio, creídos de hacerlo bien. La norma hace palidecer y menguar, trasquila y desmotiva, aun cuando la exposición se construye sobre una historia meritoria. 
Con frecuencia se reclama en nuestro espacio la redacción de historias de la revolución cubana. Pero hacerlo mal y parcializado, desde visiones y metodologías ajenas, revelar los hechos con sobredosis de narrativas - algunas veces trivializantes - , puede convertir a los consumidores de estas historias en rehenes complacientes de un pasado creado, abultado, mientras otras memorias quedan en silencio o, aparece el cansancio en el receptor por la saturación de una misma historia. Silenciamos también cuando banalizamos, trivializamos y vaciamos de contenido exacto el pasado.

Por ello la importancia de pensar en la memoria, los modos de mantenerla, de rescatar historias condenadas al silencio, historias dentro de otras historias, historias que valen no solo como memoria muerta del pasado sino para el presente. Somos responsables de la reflexión sobre asunto nada despreciable. La perspectiva crítica y no mimetizada nos devuelve el juicio sereno, acucioso, más allá de las ceremonias y la instrumentalización sin más. Se nos advierte de los olvidos, de los silencios, de la necesidad de no dar por despejado e inteligible todo lo que de nuestros procesos hemos aseverado en años. Hagamos de la memoria, de la historia, de las narrativas construidas, objeto de profunda reflexión, incorporadas al presente.

\section{Bibliografía}

Boaventura de Souza Santos (2009). Una epistemología del sur: la reinvención del conocimiento y la emancipación social. México: Siglo XXI / CLACSO.

Dussel, E. (1994). 1492: El encubrimiento del Otro. Hacia el origen del mito de la modernidad. La Paz: Plural Editores.

Fanon, F. (1965). Los condenados de la tierra. La Habana: Ediciones Venceremos. 
Fanon, F. (1968). Piel negra, máscaras blancas. La Habana: Instituto Cubano del Libro (ICL).

Hobsbawn, E. 2019 La era de las revoluciones. Madrid. Paidós

Martí, J. (1975) (1963). El plato de lentejas. Obras completas. La Habana: Editorial Nacional de Cuba. 


\section{Sobre los autores y autoras}

MIGUEL ENRÍQUEZ ESPINOSA (Talcahuano, Concepción, 1944 - Santiago de Chile, 1974). Médico y político chileno. Influenciado por la revolución cubana, en 1961 ingresó a militar en las juventudes del Partido Socialista. Es miembro fundador en 1965 del Movimiento de Izquierda Revolucionaria (MIR), convirtiéndose en 1967 en su Secretario General. Ese mismo año viajó por primera vez a La Habana, donde estrechó vínculos con autoridades e intelectuales de la Cuba revolucionaria. Tras el golpe de Estado de 1973 en Chile, lideró en la clandestinidad la resistencia popular contra la tiranía de Augusto Pinochet. El 5 de octubre de 1974, a sus 30 años, murió en un combate para vivir contra los agentes represivos de la dictadura chilena. En la actualidad es considerado uno de los intelectuales revolucionarios más destacados de Latinoamérica.

CARMEN CASTILLO ECHEVERRÍA (Santiago de Chile, 1945). Cineasta, documentalista y escritora chilena. A fines de la década de 1960 participó en la sección chilena del Ejército de Liberación Nacional 
(ELN), fundado en Bolivia por el comandante Ernesto Guevara. En 1969 ingresó a militar al Movimiento Izquierda Revolucionaria de Chile (MIR). Entre 1970 y 1971 trabajó en La Moneda, al lado de Beatriz Allende, su amiga, y del presidente Salvador Allende. Tras el golpe de Estado del 11 de septiembre de 1973 vivió en la clandestinidad luchando contra la tiranía de Augusto Pinochet. El 5 de octubre de 1974 cayó gravemente herida en un enfrentamiento contra los agentes represores de la dictadura, donde muere su compañero Miguel Enríquez. En su exilio en Francia, en 1979 escribió el libro Un día de octubre en Santiago. Ha realizado documentales como "Estado de Guerra: Nicaragua” (1984), La flaca Alejandra (1994) “La verdadera historia del Subcomandante Marcos" (1995), "El país de mi padre" (2002), Calle Santa Fe (2007), “Aún estamos vivos” (2015), “La embajada" (2019), entre muchos otros, y es considerada una de las cineastas chilenas más prestigiosas y consistentes de los últimos tiempos. Actualmente, vive entre las ciudades de Paris y Santiago, dedicada a recuperar una memoria en movimiento, no nostálgica, del proceso revolucionario, construida desde las luchas del presente.

ADRIÁN ZAPATA ROMERO (Guatemala, 1950). Ingresó a las Fuerzas Armadas Rebeldes de Guatemala (FAR), en 1965, como militante del movimiento estudiantil, primero de secundaria y luego universitaria. Se graduó en 1976 como Abogado en la Universidad de San Carlos (USAC), desempeñándose como abogado laboralista y agrario y profesor de dicha universidad. En 1978 debió salir del país y a partir de entonces se dedicó por completo a la militancia revolucionaria, a cargo del trabajo internacional y de relación con las organizaciones populares y movimientos sociales. Fue Representante de las FAR en Cuba durante los años 1980 a 1982. Posteriormente tuvo a su cargo la responsabilidad de las Escuelas de Formación Política de los frentes guerrilleros de las FAR en Guatemala. A partir de 1981 fue miembro de la Dirección Nacional de dicha organización político militar y al firmarse la paz y constituirse el partido político URNG, fue miembro del Comité Ejecutivo Nacional, primero como Secretario de 
Relaciones Internacionales y luego como Secretario de Formación Política del partido. A partir de 2004 regresa a la academia, como Profesor Titular de la Facultad de Agronomía de la Universidad de San Carlos de Guatemala, en la Sub Área de Desarrollo Rural, siendo luego el Director fundador del Instituto de Problemas Nacionales adscrito a la Rectoría de dicha universidad. Master en Política Públicas por la Universidad Rafael Landívar de Guatemala y Doctor en Ciencias Sociales por FLACSO. Ha desempeñado función pública como Secretario del Gabinete de Desarrollo Rural y actualmente es Profesor retirado de la USAC, desempeñándose eventualmente como consultor internacional para el desarrollo rural integral, entre ellos para la FAO. Durante el año 2018 fue el Asesor de la Misión de Paz de Naciones Unidas en Colombia, en el tema de tierras.

FELIX VALDÉS GARCÍA (Santa Clara, 1961). Graduado de Filosofía en Minsk, Bielorrusia, antigua república de la URSS, es actualmente profesor e investigador del Instituto de Filosofía de La Habana. Se ha dedicado al estudio de la filosofía latinoamericana, en particular del Caribe y a la recuperación de la obra crítica de pensamiento insular. Es autor de La in-disciplina de Caliban. Filosofía en el Caribe, más allá de la academia. La Habana: filosofi@.cu, 2017; Antología del Pensamiento Crítico del Caribe: West Indies, Antillas Francesas y Antillas Holandesas, CLACSO, Argentina, 2017; y Leer a Fanon medio siglo después, México: RLS, 2016, CLACSO, 2017. Actualmente coordina el Grupo de Trabajo de CLACSO “Pensamiento crítico y emancipador del Caribe". 
La memoria de las rebeliones tiene un significado político. Cuando las reinscribimos en una narración traducible hacemos con ellas "una ofrenda de sentido, no para la repetición sino para la disrupción y para la invención", afirma Diego Tatián. Sin esa acción de memoria no sería posible el advenimiento de otra cosa, distinta de lo que hay, pero también de lo que la memoria resguarda de su pérdida.

Vivimos en una región de revoluciones. La revolución ha constituido uno de los temas principales del pensamiento crítico caribeño que pretende recuperar las fuentes, las lecturas realizadas y visibilizar la trascendencia de los actos, una vez que la tórrida región es testigo de paradigmáticos procesos de su tipo. En estas islas las llamas han llegado al cielo para convertirse en sucesos, en texto esencial del mundo colonial, del Sur; procesos que después de acaecidos han forzado a Occidente a ser diferente y provocar un "giro del revés.

Félix Valdés García (COORDINADOR)

Miguel Enríquez Félix Valdés García Carmen Castillo Adrián Zapata

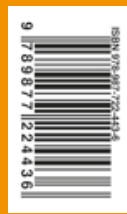

